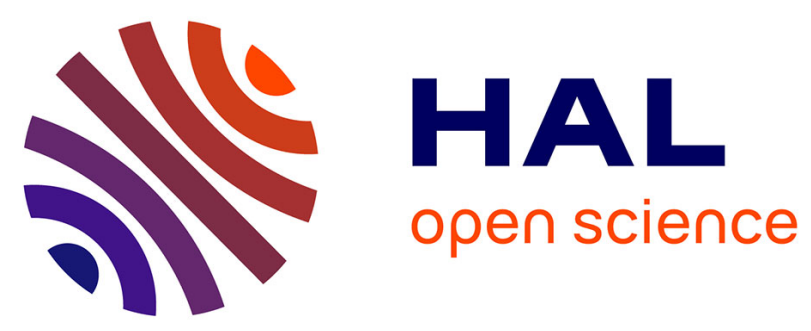

\title{
Asymmetrical structure, hydrothermal system and edifice stability: The case of Ubinas volcano, Peru, revealed by geophysical surveys
}

Katherine Gonzales, Anthony Finizola, Jean-François Lénat, Orlando Macedo,

Domingo Ramos, Jean-Claude Thouret, Michel Fournier, Vicentina Cruz,

Karine Pistre

\section{To cite this version:}

Katherine Gonzales, Anthony Finizola, Jean-François Lénat, Orlando Macedo, Domingo Ramos, et al. Asymmetrical structure, hydrothermal system and edifice stability: The case of Ubinas volcano, Peru, revealed by geophysical surveys. Journal of Volcanology and Geothermal Research, 2014, 276, pp.132-144. 10.1016/j.volgeores.2014.02.020 . hal-01136351

\section{HAL Id: hal-01136351 \\ https://hal.science/hal-01136351}

Submitted on 19 May 2017

HAL is a multi-disciplinary open access archive for the deposit and dissemination of scientific research documents, whether they are published or not. The documents may come from teaching and research institutions in France or abroad, or from public or private research centers.
L'archive ouverte pluridisciplinaire $\mathbf{H A L}$, est destinée au dépôt et à la diffusion de documents scientifiques de niveau recherche, publiés ou non, émanant des établissements d'enseignement et de recherche français ou étrangers, des laboratoires publics ou privés. 


\section{Asymmetrical structure, hydrothermal system and edifice stability: The case of Ubinas volcano, Peru, revealed by geophysical surveys}

Katherine Gonzales ${ }^{\mathrm{a}, *}$, Anthony Finizola ${ }^{\mathrm{b}, 1}$, Jean-François Lénat ${ }^{\mathrm{b}}$, Orlando Macedo ${ }^{\text {a }}$, Domingo Ramos ${ }^{\mathrm{a}, 2}$, Jean-Claude Thouret ${ }^{\mathrm{c}}$, Nicolas Fournier ${ }^{\mathrm{b}, 3}$, Vicentina Cruz ${ }^{\mathrm{a}, 2}$, Karine Pistre ${ }^{\mathrm{b}, \mathrm{c}}$

a Instituto Geofísico del Perú (IGP), Arequipa, Peru

b Clermont Université, Université Blaise Pascal, Laboratoire Magmas et Volcans, IRD, R 163, CNRS, UMR 6524, BP 10448, 63038 Clermont-Ferrand, France

c Université de Lorraine, UMR 7359 GeoRessources, BP 70239, Vandoeuvre-lès-Nancy, France

A B S T R A C T

Ubinas volcano, the historically most active volcano in Peru straddles a low-relief high plateau and the flank of a steep valley. A multidisciplinary geophysical study has been performed to investigate the internal structure and the fluids flow within the edifice. We conducted 10 self-potential (SP) radial (from summit to base) profiles, 15 audio magnetotelluric (AMT) soundings on the west flank and a detailed survey of SP and soil temperature measurements on the summit caldera floor. The typical "V" shape of the SP radial profiles has been interpreted as the result of a hydrothermal zone superimposed on a hydrogeological zone in the upper parts of the edifice, and depicts a sub-circular SP positive anomaly, about $6 \mathrm{~km}$ in diameter. The latter is centred on the summit, and is characterised by a larger extension on the western flank located on the low-relief high plateau. The AMT resistivity model shows the presence of a conductive body beneath the summit at a depth comparable to that of the bottom of the inner south crater in the present-day caldera, where intense hydrothermal manifesta-tions occur. The lack of SP and temperature anomalies on the present caldera floor suggests a self-sealed hydro-thermal system, where the inner south crater acts as a pressure release valve. Although no resistivity data exists on the eastern flank, we presume, based on the asymmetry of the basement topography, and the amplitude of SP anomalies on the east flank, which are approximately five fold that on the west flank, that gravitational flow of hydrothermal fluids may occur towards the deep valley of Ubinas. This hypothesis, supported by the presence of hot springs and faults on the eastern foot of the edifice, reinforces the idea that a large part of the southeast flank of the Ubinas volcano may be altered by hydrothermal activity and will tend to be less stable. One of the major findings that stems from this study is that the slope of the basement on which a volcano has grown plays a major role in the geometry of the hydrothermal systems.

Another case of asymmetrical composite cone edifice, built on a steep topography, is observed on El Misti volcano (situated $70 \mathrm{~km}$ west of Ubinas), which exhibits a similar SP pattern. These types of edifices have a high potential of spreading and sliding along the slope owing to the thicker accumulation of low cohesion and hydrothermally altered volcanic products.

\footnotetext{
* Corresponding author at: Instituto Geológico, Minero y Metalúrgico (INGEMMET), Lima, Peru.

E-mail addresses: kgonzales@ingemmet.gob.pe (K. Gonzales), anthony.finizola@gmail.com (A. Finizola),J.F.Lenat@opgc.univ-bpclermont.fr (J.-F. Lénat), orlando.macedo@igp.gob.pe (O. Macedo),dramos@ingemmet.gob.pe (D. Ramos),

J.C.Thouret@opgc.univ-bpclermont.fr (J.-C. Thouret), n.fournier@gns.cri.nz (N. Fournier), vcruz@ingemmet.gob.pe (V.Cruz), karine.pistre@univ-lorraine.fr (K. Pistre).

1 Now: Laboratoire GéoSciences Réunion, Université de la Réunion, Institut de Physique du Globe de Paris, Sorbonne Paris-Cité, CNRS, UMR 7154, 97715 La Réunion, Indian Ocean, France.

2 Now: Instituto Geológico, Minero y Metalúrgico (INGEMMET), Lima, Peru.

3 Now: Wairakei Research Centre, GNS Science, Private Bag 2000, Taupo 3352, New Zealand.
}

\section{Introduction}

Understanding the inner structure of a composite cone through geophysical survey can help to provide crucial insights into past eruptive history and the structural relationships between the edifice and regional tectonics. Among the major features that can influence the cone behaviour for future activity are the existence of faults and lithological discontinuities (such as those created by calderas or landslides) and the presence of a hydrothermal system that determines the fluid flows and the alteration of the edifice (Lopez and Williams, 1993; Reid et al., 2001). In this study of Ubinas volcano (south Peru), we used the self- 
potential (SP) technique and soil temperature measurements to outline the hydrothermal system and audio-magnetotelluric (AMT) measurements to investigate the internal structure through the distribution of resistivity. Moreover, the location and temperature of the water springs in a radius of $20 \mathrm{~km}$ all around Ubinas volcano have been taken. Information on the hydrothermal system is important because it is part of the plumbing system and as such, it plays a role on the eruptive activity. This is particularly true in the case of the last Ubinas eruption in 2006-2009 (Rivera et al., 2014).

The SP method has been used on active volcanoes for identifying and delineating anomalies associated with the presence of active hydrothermal systems (Lénat et al., 1998; Finizola et al., 2002, 2003; Aizawa, 2004; Revil et al., 2004; Hase et al., 2005; Finizola et al., 2006; Aizawa et al., 2008; Revil et al., 2008; Barde-Cabusson et al., 2009a,b; Finizola et al., 2009, 2010; Bennati et al., 2011; Revil et al., 2011; Barde-Cabusson et al., 2012). This method can also be used to monitor the evolution of hydrothermal systems through time (Ishido et al., 1997; Yasukawa et al., 2005). SP anomalies due to the hydrothermal activity can reach hundreds to thousands of millivolts in amplitude (Finizola et al., 2004). These surface electric fields reflect streaming current effects occurring at depth. The main source of SP signal on volcanoes is thought to be electrokinetic coupling (Corwin and Hoover, 1979). Electrokinetic (or streaming) potentials are generated when a fluid flows through a porous medium (electro-osmosis) generating electric current and voltage difference in the double electrical layer (Corwin and Hoover, 1979; Avena and De Pauli, 1996; Lorne et al., 1999a,b; Revil and Leroy, 2001). The external layer, termed the electrical diffuse layer, is generally positively charged. The fluid flow drags positive charges from the diffuse layer, creating a macroscopic current density and an electrical field called the streaming potential. The current is therefore positive in the flow direction. This has been documented by laboratory experiments for silica and volcanic rocks (e.g. Ishido and Mizutani, 1981; Jouniaux et al., 2000), theoretical works (Lorne et al., 1999a,b; Revil et al., 1999a,b; Revil and Leroy, 2001), and field data (e.g. Trique et al., 1999). As a result, the electrokinetic effect associated with the down flow of water in purely hydrogeological zones results in negative self-potential anomalies at the ground surface, whereas the uprising flow in hydrothermal systems will result in positive anomalies. In hydrogeological zones, the amplitude of the SP variation can be related to the distance between the topography and the water table (Jackson and Kauahikaua, 1987; Aubert et al., 1993; Aubert and Atangana, 1996; Boubekraoui et al., 1998; Revil et al., 2005). However, several cases of negatively charged electrical diffuse layer (positive zeta potential) have been reported for rocks and minerals located above hydrothermal areas and also for all minerals (with the exception of clays such as smectite) when the $\mathrm{pH}$ is below the isoelectric point of the mineral, typically for acidic solutions (Guichet and Zuddas, 2003; Hase et al., 2003; Guichet et al., 2006; Aizawa et al., 2008). This means that, under certain conditions (type of particles, bulk solution, temperature, $\mathrm{pH}$ ), either SP maxima or minima can be measured with the same fluid circulation direction. But in most cases, SP profiles extending from the summit to the lower flanks of active volcanoes show two major SP domains (e.g. Sasai et al., 1997; Aubert et al., 2000; Finizola et al., 2004; Ishido, 2004). In the upper part of the edifice, the SP is generally dominated by hydrothermal flow with positive SP/elevation gradient, whereas in the lower flanks, hydrogeological flow is mostly expected with negative SP/elevation gradient.

This work has consisted in mapping extensively SP anomalies across the entire Ubinas composite cone about $10 \mathrm{~km}$ in diameter. In addition, 15 audio-magnetotelluric (AMT) soundings provided a resistivity crosssection of the western flank of the edifice. A detailed SP and soil subsurface temperature mapping was conducted on the floor of the summit caldera, covering an area of about $1 \mathrm{~km}$ in diameter. Finally, water springs, well known by the local inhabitants, where located and measured in temperature, in a radius of $20 \mathrm{~km}$ all around the volcanic edifice. Here we present results from each individual survey before drawing conclusions from their integrated interpretation. We then compare our findings with nearby Peruvian volcanoes (El Misti and Tiscani) where similar measurements have been conducted (Finizola et al., 2004; Byrdina et al., 2013). Finally, we discuss the implications of this study on hazard assessment at Ubinas volcano.

\section{Geological setting}

Ubinas volcano $\left(16^{\circ} 21^{\prime} \mathrm{S}, 70^{\circ} 54^{\prime} \mathrm{W}, 5675 \mathrm{~m}\right.$ asl $)$ is an andesitic composite cone with a roughly circular shape, located in the Western Cordillera in the Central Andean Volcanic Zone (CVZ in Fig. 1a). Ubinas is part of a calc-alkaline volcanism of Quaternary age and belongs to the volcanic range emplaced during the Pleistocene. This volcanic range is related to the subduction of the Nazca plate beneath the South American plate, with an average velocity of $4.6 \mathrm{~cm} / \mathrm{yr}$ (Sébrier and Soler, 1991). Seven of these volcanoes in southern Peru have experienced historical (i.e. post-Spanish conquest) eruptive crises: Nevado Sabancaya, El Misti, Ubinas, Huaynaputina, Ticsani, Tutupaca and Yucamane (Hantke and Parodi, 1966; James, 1982; De Silva and Francis, 1991; Simkin and Siebert, 1994).

Ubinas volcano has been built mainly on Tertiary age volcanic products: Eocene and Oligocene products (lava flows and ignimbrites) from Tacaza Group and Mio-Pliocene products from the 'Barroso' Group (Marocco and del Pino, 1966). The eruptive history of Ubinas, beginning in the early Pleistocene, is divided into two major periods: Ubinas I and Ubinas II (Thouret et al., 2005). A first edifice, Ubinas I, no more than 600 $\mathrm{m}$ high, has been built acquiring a shield-like morphology. The Ubinas I period has encompassed three major stages (Ia, Ib and Ic): Stage Ia (>376 kyr) is essentially effusive; Stage Ib is characterised by a sector collapse of Ubinas I edifice which left a large horseshoe-shaped amphitheather open toward the SSE (Fig. 1B); Stage Ic ( $376 \mathrm{kyr})$, a succession of voluminous $\left(1.8 \mathrm{~km}^{3}\right)$ non-welded ash-and-pumice flow deposits with lithic-rich pyroclastic-flow deposits, is associated to an old summit caldera formation.

A huge unconformity visible in the south and the southeast flank of the volcano points to the boundary between Ubinas I and Ubinas II products. The second Ubinas edifice, a lava stratocone more than $900 \mathrm{~m}$ high, has overlain Ubinas I. Five units have been distinguished during the Ubinas II period: IIa, IIb, IIc, IId and IIe. During Stage IIa (between 376 and $142 \mathrm{kyr}$ ), a thick succession of andesite and dacite block-lava flows has formed the upper part of the edifice. Stage IIb $(\sim 250 \mathrm{kyr})$ was a period of dacitic dome growth and destruction. These two first periods of Ubinas II growth have been followed by a quiescence period or a time interval of erosion between 142 and 25 kyr. Stage IIc (between 25 and $9.7 \mathrm{kyr}$ ) resulted from a series of massive ash-rich flow and Plinian pumice-fall deposits. During Stage IId (between 7500 and $3670 \mathrm{yr}$ BP), small and medium-scale sub-Plinian, phreatomagmatic and vulcanian eruptions occurred. Flank failure and rockslides occurred again on the unstable south flank at the end of this period. The gravitational collapse of the south flank ( $3670 \pm 60 \mathrm{yr}$ BP) has emplaced hummocks of debris-avalanche deposits upstream of the Ubinas valley about $4 \mathrm{~km}$ away from the summit. A volume of approximately $2.5-2.8 \mathrm{~km}^{3}$ of debris avalanche deposits has been located along Ubinas Valley (Thouret et al., 2005; Rivera et al., 2014). During Stage Ile (between $3670 \mathrm{yr}$ and present), the last Plinian eruption occurred c. $980 \mathrm{yr}$ BP. The present-day caldera has been formed by a succession of Plinian eruptions that occurred since $7500-15,000$ yr BP. During the past 1000 years, the activity has been dominated by abundant but small-sized phreatic, phreatomagmatic, and vulcanian eruptions. No less than 24 eruptive events, including substantial fumarolic crises, have occurred since $1550 \mathrm{AD}$. As a consequence, Ubinas is considered the most active volcano of Peru, with three to five small events per century (Hantke and Parodi, 1966; Simkin and Siebert, 1994; Valdivia, 1995; Rivera et al., 1998; Thouret et al., 2005). The last eruptive crisis, largely dominated by phreatic and phreatomagmatic activity, started on March 2006 and ended late 2008 (Rivera et al., 2010). 

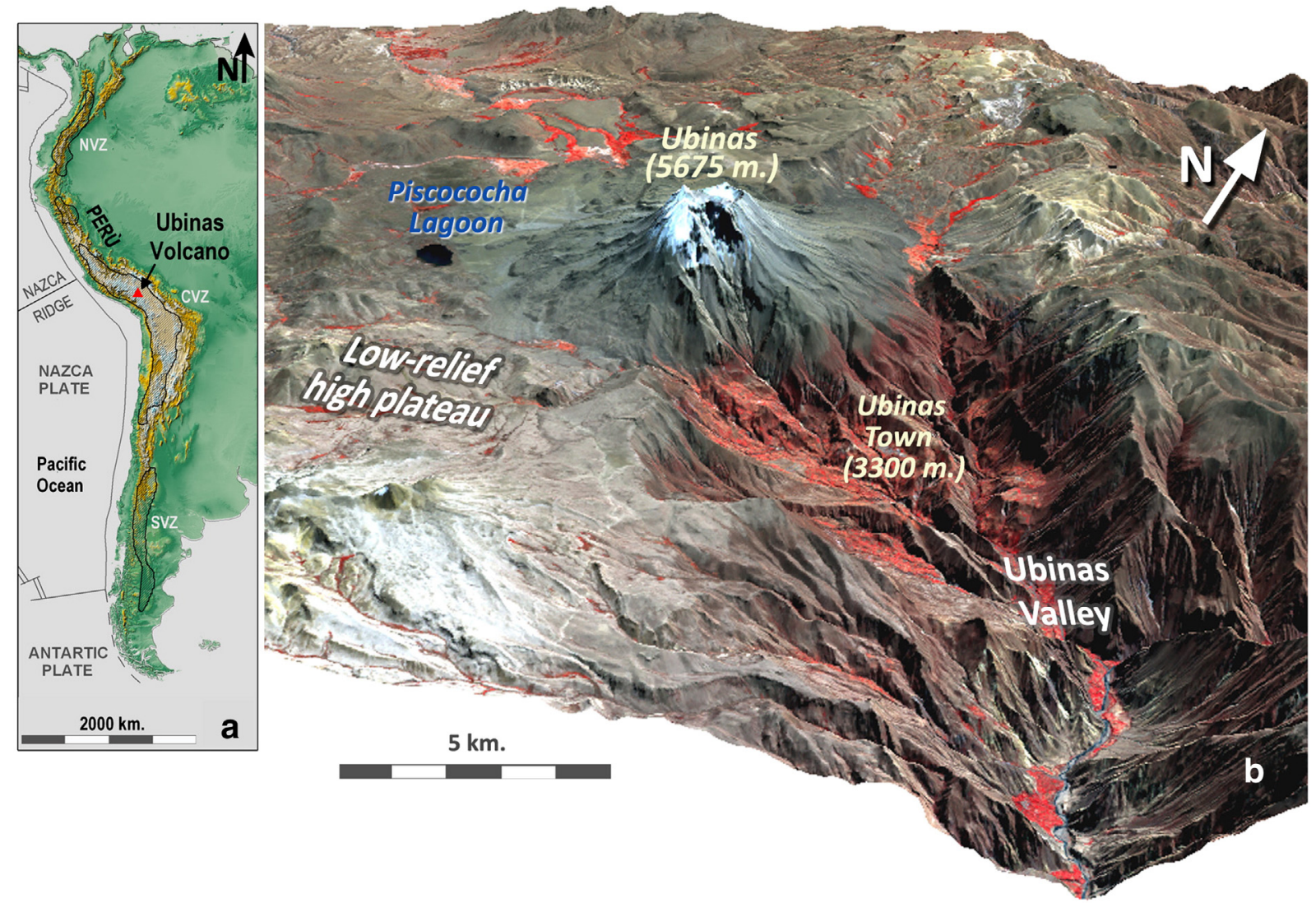

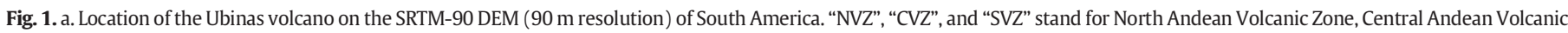

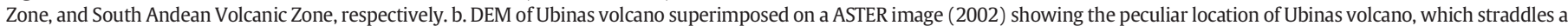
staircase-like morphology between the low-relief high plateau and the steep valley flank of Ubinas.

The Ubinas edifice has a peculiar structural position for it straddles a low-relief high plateau to the west and the deep valley of Ubinas to the east (where the town of Ubinas is located) (Fig. 1b). During the period Ubinas Ib and IId, the south flank of Ubinas edifice have been affected by large landslides and flank failures towards the Ubinas valley (Thouret et al., 2005; Fig. 1b).

The summit of Ubinas volcano is occupied by a slightly elliptical, N-S elongated caldera with maximum diameter of $1.4 \mathrm{~km}$ (Fig. 2a). In the middle part of the flat floor of the caldera, two adjacent lapilli and ash cones, a few tens of metres high, have been built after the last Plinian eruption at about $980 \mathrm{yr}$ BP. They are herein referred to as "E crater" and "W crater". In the southern part of the caldera lies a pit crater of about $400 \mathrm{~m}$ in diameter and $300 \mathrm{~m}$ in depth (Rivera, 1997; Thouret et al., 2005; see Fig. 2b). This pit crater, herein referred to as "S crater", is the present-day crater, and cuts the two adjacent cones. The south border of the pit crater rests against the south border of the caldera rim (Fig. 2a, b), where layers of lava are greatly affected by fracturing and hydrothermal alteration. In the 1970 s, a small water lake was located at the bottom of the pit crater ( $\mathrm{R}$. Marocco, personal communication). Before the most recent eruptive episode, which began in March 2006, six fumarolic areas were emitting volcanic gas and steam (see Fig. $2 \mathrm{~b}$ ) at the bottom of the crater. We observed three groups of fumaroles: (1) the fumaroles nos. 1, 2, and 3 located on the lower inner flank of, and corresponding to the border fault of, an old crater, (2) the fumaroles nos. 4 and 5, corresponding to the border fault of the last crater located on the bottom of the present-day S crater, and (3) the fumarole no. 6 , located in a hole about $4 \mathrm{~m}$ in diameter and showing the highest temperatures ( $444{ }^{\circ} \mathrm{C}$ measured in July 1997). In 1997-98 the fumarole no. 5 was emitting gas at high pressure, with a jet-like noise audible from the caldera rim, several hundred metres away from the $S$ crater. On the northwest part of the crater, close to the bottom, an intermittent water spring was observed in July 1997. The water samples from August 1998 revealed the very high acid concentration $(\mathrm{pH}<2)$ : the silicone tops of the three standard glass tubes were entirely corroded in few hours. This acid spring is responsible for the wet area on the ash deposits located in the bottom of the crater (see "wet area" in Fig. 2b). In July 1997, four times in 12 days, spectacular events of increased gas emission have been observed, with a cloud of gas filling the caldera and spilling out on the flanks (Fig. 2a). This phenomenon was observed only at night, suggesting that the cold night temperature (minimum of $-23{ }^{\circ} \mathrm{C}$ at this period) may have played a role by cooling, and thus quickly increasing their density and generating their accumulation inside the caldera. Few hours after sunrise, the gas plume was totally diluted in the atmosphere. No fumarolic activity has been observed on Ubinas volcano outside of the $\mathrm{S}$ crater.

\section{Data acquisition and processing}

Self-potential, subsurface soil temperature, and controlled source audio-magnetotelluric surveys were performed at Ubinas volcano on two different scales: SP and CS-AMT surveys extended to the entire volcanic edifice, whereas a second, more detailed survey, combining SP and temperature, was carried out inside the summit caldera. Water springs were listed and measured in temperature on a radius of about $20 \mathrm{~km}$ all around the volcanic edifice.

\subsection{The edifice geophysical survey}

\subsubsection{Self-potential (SP) survey}

The equipment used for the self-potential (SP) measurements included two $\mathrm{Cu} / \mathrm{CuSO}_{4}$ non-polarising electrodes, a high impedance voltmeter and an insulated Cu cable $300 \mathrm{~m}$ long. The SP survey at the 

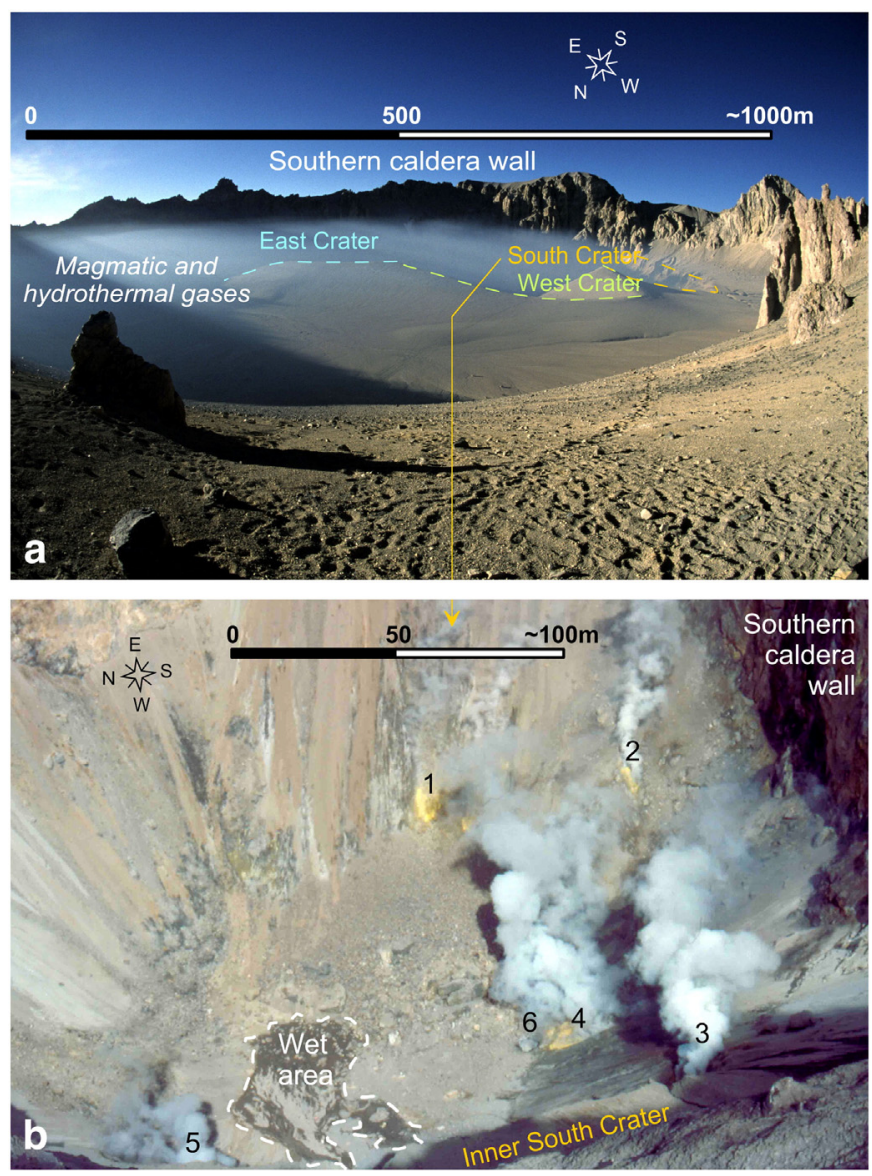

Fig. 2. a. Picture looking south of the summit caldera of Ubinas filled with gas (see text). S (south) crater is located adjacent to the south caldera wall (July 1997). b. Picture looking east of the bottom of the south crater ( $5075 \mathrm{~m}$ asl.) showing six fumaroles and a wet area supplied by an acid spring located at about $5100 \mathrm{~m}$ asl. (July 1997).

scale of the volcanic cone was carried out prior to the 2006-2008 eruption during three field campaigns: November-December 1998, December 1999 and December 2002 for a profile total length of $86.6 \mathrm{~km}$. The measurements were performed along ten radial profiles with a $100 \mathrm{~m}$ sampling step. Nine of them extended from the summit to the lower flanks of the volcano and one profile (7) started from the upper part of profile 8 (Fig. 3). Two SP closure lines were carried out in order to tie the radial profiles; one in the upper part (caldera border) of the survey and the other one at the lower end of radial profiles. The Piscococha lagoon (Fig. 3 ) was chosen as the SP reference $(0 \mathrm{mV})$ as it probably represents the level of the regional water table. Linear closure corrections were computed for all the SP profiles. Closure corrections of less than $170 \mathrm{mV}$ were observed for 8 profiles, and of more than $300 \mathrm{mV}$ for two other profiles (profiles 2 and 8 ).

Because of the radial pattern of the surveys, data coverage is highly heterogeneous, with a high density of data along the profiles but large areas devoid of data between them. As a result, building a SP map using a simple interpolation would yield non-realistic values between profiles, especially across the lower part of the edifice. The interpolation of the data was therefore achieved in two steps. First, the data was interpolated using a mesh resolution 10 times wider $(1000 \mathrm{~m})$ than the sampling interval along the radial profiles. Second, using the values of this low-resolution grid and the original data the final SP map was interpolated with a mesh of $70 \mathrm{~m}$ (Fig. 3). This way, the high frequency information along the profiles is maintained while a smooth and coherent interpolation between profiles is achieved. On the south flank (between radial profiles 1 and 10), where no data coverage is available due to its inaccessibility, the interpolation has not been constrained.

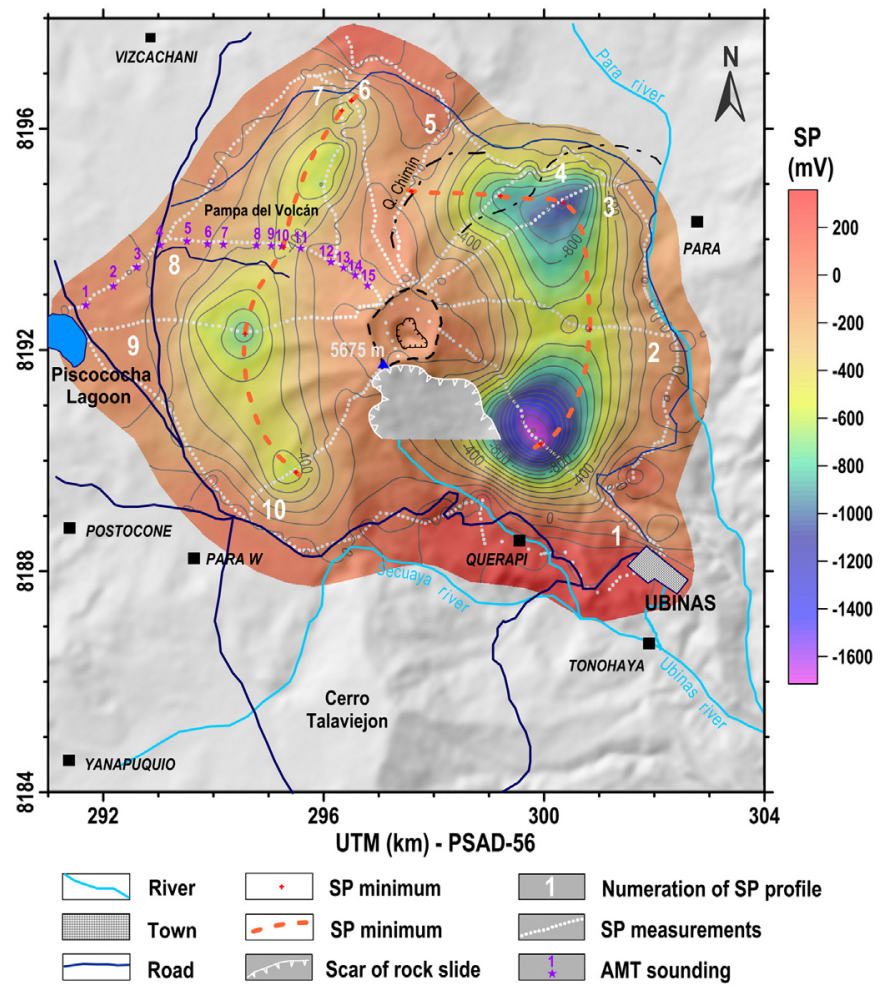

Fig. 3. Self-potential (SP) map of the Ubinas volcano superimposed on a SRTM-90 DEM (90 m resolution). The map exhibits a clear asymmetry in amplitude between the lowrelief high plateau and the Ubinas valley. The hydrothermal system is approximately $6 \mathrm{~km}$ in diameter.

This area has therefore been blanked out on the map, inside the structural area delineated by the scar of rockslide of the south flank, to avoid misinterpretation.

\subsubsection{Controlled source - audio-magnetotelluric (CS-AMT) survey}

With the AMT method, natural electromagnetic fields are used to investigate the resistivity structure of the Earth (Strangway et al., 1973; Vozoff, 1991; Zonge and Hughes, 1991). The amplitude, phase, and directional relationships between electric and magnetic fields on the surface depend on the distribution of the electrical resistivity at the subsurface. Fifteen AMT soundings, measured along the Pampa del Volcán SP profile (profile 8 in Fig. 3), provided a W-E resistivity crosssection of the western flank of Ubinas. An abnormally thick snow cover at the time of the measurements (April-Mai 1999) hampered soundings in the summit area. We used a Stratagem EH4 (Geometrics) CSAMT (controlled source audio-frequency magnetotellurics) equipment allowing to record data in the $10 \mathrm{~Hz}-92 \mathrm{kHz}$ frequency range. A controlled source provided signals in the frequency range of $1 \mathrm{kHz}$ to $70 \mathrm{kHz}$ and was separated from the recording station from a distance sufficient to be in the so-called far-field (plane-wave condition) (Sasaki et al., 1992) The Stratagem system records orthogonal electric and magnetic horizontal fields, which are processed to provide tensor impedance measurements. When considering tensor measurements, we identify the transverse electric (TE) and transverse magnetic (TM) orthogonal components (e.g. Dobrin and Savit, 1988). For the TE mode, the electric field parallels the direction of the inferred 2-D underlying structures. Assuming that the main structures of the Ubinas stratocone are more or less concentric to the summit, we associate TE mode with the tangential electric field. In the field, the setup of the electrode lines and the magnetic sensors was always oriented in line and perpendicular to the summit, and hence no rotation was applied to the data to obtain TE and TM components. The data were processed using the WinGLink ${ }^{\circledR}$ package from GeoSystem. Several 2-D inversions 


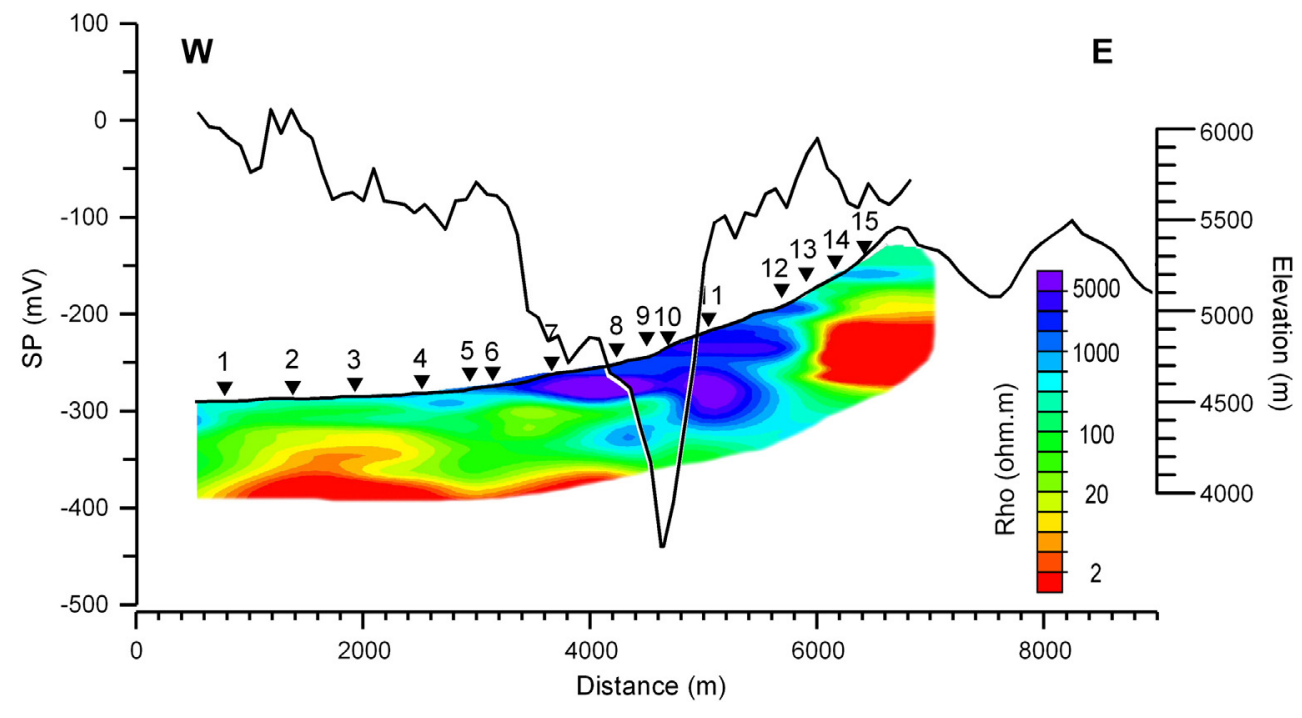

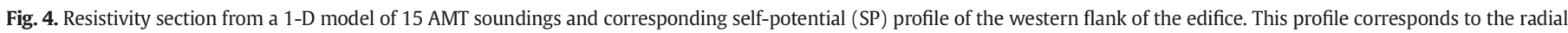
profile 8 shown in Fig. 2.

using TE and TM apparent resistivity and phases simultaneously or only either the TE or TM components were carried out, as well as Occam (Constable et al., 1987) and Bostick (Bostick, 1977) 1-D inversions. Given the moderate quality of the data (see Figures in the Electronic Data Supplement (EDS)), it has proven difficult to obtain significantly different and reliable models with different approaches. For this reason, we have chosen to present the simplest model, i.e. the 1D Occam model on the TM component in Fig. 4. Resistivity values were interpolated between the soundings to obtain the west flank AMT section.

\subsubsection{Temperature measurement and chemical composition of water springs}

Cold and hot water springs are very well known by the local inhabitants. Sampling and temperature measurements were conducted between 1997 and 2010 (in September 1997, May 1998, April 2006, and July 2010). For the structural purpose, we aimed to locate and identify cold and hot springs and their chemical characteristics, and to reveal the degree of contamination from a magmatic end-member $\left(\mathrm{SO}_{4}\right)$ in an area of about $20 \mathrm{~km}$ around Ubinas edifice. We present the average temperature values and the major chemical components of each spring (Table 1$)$. The components appear in a triangular $\left(\mathrm{SO}_{4}, \mathrm{Cl}, \mathrm{HCO}_{3}\right)$ ‘Giggenbach' diagram (Fig. 5).

\subsection{The caldera survey}

\subsubsection{SP and temperature}

Soil temperature taken at few tens of centimetres depth is generally used to locate hydrothermal fluids preferentially rising close to the surface along structural boundaries (Aubert et al., 2007; Peltier et al., 2012). A total of 2698 self-potential (SP) and 2704 soil temperature measurements were performed simultaneously on the summit caldera floor, during a field campaign in June 1997, in order to investigate the hydrothermal fluid flows around the only visible fumarolic area located inside S crater. SP and temperature were measured along 41 parallel $\mathrm{E}-\mathrm{W}$-trending profiles and one N-S trending profile (Fig. 6a and b). The distance interval between the stations along the profiles was $5 \mathrm{~m}$, with profiles spacing of $20 \mathrm{~m}$. For temperature measurements, we dug $20 \mathrm{~cm}$-deep holes in the ash products and measured immediately the temperature using an infrared thermometer with a resolution of $1{ }^{\circ} \mathrm{C}$.

The temperatures of the fumaroles located inside the $\mathrm{S}$ crater were also measured using an infrared thermometer during a separate campaign in August 1998. Because of the high spatial density and grid-like distribution of the SP and temperature measurements inside the Ubinas caldera, a simple interpolation was used to produce the SP and temperature maps (Fig. 6a and b).

\section{Data interpretation}

\subsection{Across the entire volcanic edifice}

\subsubsection{SP survey}

Each of the SP radial profiles across the Ubinas volcano (Figs. 3 and 7) shows a typical "V" shape (e.g. Finizola et al., 2004; Ishido, 2004), which reflects (1) a hydrogeological zone in the lower part of the edifice, characterised by a negative SP/altitude gradient and (2) an adjacent hydrothermal zone, in the upper part of the edifice, characterised by a positive SP/altitude gradient. This boundary is located between 4350 and $4750 \mathrm{~m}$ asl. However, the amplitude of the " $\mathrm{V}$ " shape varies between profiles, with an up to fivefold amplitude difference between the western and the eastern profiles. In addition, the bottoms of the "V" shape (i.e. the minima) do not show a progressively concentric pattern around the volcano summit, but define two arcuate lines located on the plateau to the west and on the valley side to the east (Fig. 3). The lowest amplitude "V" shape appears along profile 5 , which runs along the boundary subdividing the hydrogeological zone and the hydrothermal zone (Figs. 3, 7).

We therefore clearly distinguish, based on the interpretation of SP data, the western flank built up on the low-relief high plateau and the thicker east flank. The larger amplitude of the minima on the east flank may be explained by a much thicker vadose zone in this area (Jackson and Kauahikaua, 1987). In the valley, we can assume that the water table corresponds more or less to the altitude of the river. On the high plateau, the presence of the Piscococha lagoon suggests the presence of a shallow water table. Thus, the surface of the Ubinas volcano beneath the minima is only of about $200 \mathrm{~m}$ above the water table to the west, whereas the corresponding distance interval reaches about $1000 \mathrm{~m}$ on the east flank.

Conversely, along the rim of the valley, the amplitude of the SP minimum is the lowest to the north (profile 5) but there is no data at the south. A possible explanation is that the hydrothermal system is markedly elongated between the two contrasted flanks of the edifice. The hydrothermal system would thus counteract the hydrogeological gradient at the south and the north. The presence 
Table 1

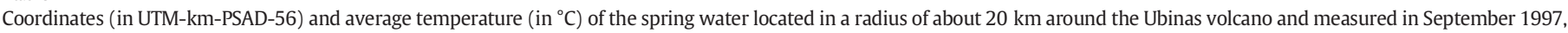
May 1998, April 2006, and July 2010. Symbols and colours as in Figs. 5 and 8.

\begin{tabular}{|c|c|c|c|c|c|c|c|c|}
\hline \multirow{2}{*}{ No. } & \multirow{2}{*}{ Fuentes Ubinas } & \multirow{2}{*}{ Symbol } & $\mathrm{X}$ & $\mathrm{Y}$ & \multirow{2}{*}{$\begin{array}{c}\text { Altitude } \\
(\mathrm{m})\end{array}$} & \multirow{2}{*}{$\mathrm{pH}$} & \multirow{2}{*}{$\begin{array}{c}\mathrm{CE} \\
(\mu \mathrm{s} / \mathrm{cm})\end{array}$} & \multirow{2}{*}{$\begin{array}{c}\text { Temp } \\
\left({ }^{\circ} \mathrm{C}\right)\end{array}$} \\
\hline & & & \multicolumn{2}{|c|}{ UTM-(km) PSAD-56 } & & & & \\
\hline 1 & Puente a Lucco & PL & 313.531 & 8197.200 & 3077 & 6.7 & 20,700 & 40.6 \\
\hline 2 & Huarina & $\mathrm{Hr} 1$ & 306.694 & 8180.945 & 3380 & 6.9 & 2590 & 40.0 \\
\hline 3 & Matalaque & Mt & 306.085 & 8177.409 & 2500 & 6.8 & 1003 & 39.5 \\
\hline 4 & Lojen 1 & Lg1 & 286.401 & 8182.630 & 4506 & 4.3 & 1340 & 38.6 \\
\hline 5 & Tacune & Tc & 286.697 & 8182.844 & 4460 & 3.8 & 1800 & 38.2 \\
\hline 6 & Baños Lloque & BL & 314.092 & 8195.959 & & & & 36.8 \\
\hline 7 & Bano de Cura II & $\mathrm{BC} 2$ & 315.191 & 8203.504 & 3539 & 6.4 & 12,570 & 35.6 \\
\hline 8 & Eschaje II & Es2 & 315.148 & 8203.615 & 3463 & 7.1 & 10,300 & 34.1 \\
\hline 9 & Huarina II & $\mathrm{Hr} 2$ & 306.403 & 8180.459 & 2512 & 7.3 & 2070 & 34.0 \\
\hline 10 & Eschaje I & Es1 & 315.225 & 8203.487 & 3480 & 6.1 & 10,850 & 31.2 \\
\hline 11 & Lucco & Lc & 313.609 & 8197.111 & 3070 & 7.0 & 13,000 & 31.0 \\
\hline 12 & Baños del Cura & BC1 & 315.102 & 8202.351 & 3492 & 6.4 & 8590 & 30.4 \\
\hline 13 & Lojen II & Lg2 & 286.282 & 8182.600 & 4487 & 4.4 & 1330 & 30.0 \\
\hline 14 & Ubinas Termal & Ut & 301.733 & 8188.459 & 3267 & 5.9 & 1686 & 29.6 \\
\hline 15 & Chiflon & $\mathrm{Ch}$ & 301.212 & 8188.037 & 3437 & 6.0 & & 28.9 \\
\hline 16 & Volcancito & $\mathrm{Vl}$ & 286.529 & 8182.472 & 4497 & 3.6 & 600 & 20.1 \\
\hline 17 & Ubinas Fría & Uf & 301.743 & 8188.570 & 3267 & 7.0 & 671 & 15.0 \\
\hline 18 & Santa Rosa de Para & SRP & 302.173 & 8195.037 & 4200 & 5.7 & & 12.5 \\
\hline 19 & Para Este & PE & 300.641 & 8199.466 & 4190 & 7.9 & 67 & 11.5 \\
\hline 20 & Ispay Puquio I & IP1 & 296.912 & 8188.769 & 4102 & 6.4 & 291 & 11.4 \\
\hline 21 & Laguna Piscococha & LP & 291.787 & 8192.837 & 4380 & 6.0 & & 11.2 \\
\hline 22 & Ispay Puquio II & IP2 & 296.505 & 8188.288 & 4107 & 6.8 & 245 & 10.6 \\
\hline 23 & Tambillo & $\mathrm{Tb}$ & 296.141 & 8187.795 & 4146 & 7.4 & 213 & 10.4 \\
\hline 24 & Pampa de Para W & PW & 294.219 & 8188.404 & 4271 & 7.2 & 214 & 8.1 \\
\hline 25 & Cruz Matalaque & $\mathrm{CM}$ & 305.422 & 8177.536 & 2500 & 7.9 & 80.3 & 8.0 \\
\hline
\end{tabular}

\begin{tabular}{|l|c|r|r|r|r|r|r|r|}
\hline $\begin{array}{c}\text { Color ref. } \\
\text { water type }\end{array}$ & $\begin{array}{c}\mathrm{Li} \\
(\mathrm{mg} / \mathrm{L})\end{array}$ & $\begin{array}{c}\mathrm{Na} \\
(\mathrm{ppm})\end{array}$ & $\begin{array}{c}\mathrm{K} \\
(\mathrm{mg} / \mathrm{L})\end{array}$ & $\begin{array}{c}\mathrm{Mg} \\
(\mathrm{mg} / \mathrm{L})\end{array}$ & $\begin{array}{c}\mathrm{Ca} \\
(\mathrm{mg} / \mathrm{L})\end{array}$ & $\begin{array}{c}\mathrm{Cl} \\
(\mathrm{mg} / \mathrm{L})\end{array}$ & $\begin{array}{c}\mathrm{SO}_{4} \\
(\mathrm{mg} / \mathrm{L})\end{array}$ & $\begin{array}{c}\mathrm{HCO}_{3} \\
(\mathrm{mg} / \mathrm{L})\end{array}$ \\
\hline $\mathrm{Cl}$ type & 7.1 & 3746.0 & 197.0 & 55.0 & 398.6 & 6249.4 & 1143.8 & 634.4 \\
\hline $\mathrm{SO}_{4}$ type & 1.1 & 295.8 & 12.9 & 32.4 & 308.2 & 401.2 & 693.1 & 219.6 \\
\hline $\mathrm{SO}_{4}$ type & 0.7 & 117.5 & 9.4 & 6.8 & 79.2 & 116.1 & 184.8 & 183.0 \\
\hline $\mathrm{SO}_{4} \sim 100 \%$ & 0.1 & 67.0 & 12.0 & 8.5 & 230.0 & 5.5 & 680.3 & 1.2 \\
\hline $\mathrm{SO}_{4}$ type & 0.1 & 60.0 & 11.0 & 9.0 & 315.0 & 11.0 & 727.0 & 0.0 \\
\hline $\mathrm{Not}_{\text {determined }}$ & & & & & & & & \\
\hline $\mathrm{Cl}$ type & 5.0 & 2233.3 & 152.5 & 30.1 & 152.4 & 3461.3 & 286.1 & 932.1 \\
\hline $\mathrm{Cl}_{\mathrm{Sype}}$ & 5.3 & 2080.7 & 131.0 & 25.3 & 186.1 & 3013.3 & 307.0 & 915.9 \\
\hline $\mathrm{SO}_{4}$ type & 1.0 & 302.9 & 14.0 & 33.5 & 317.6 & 377.7 & 712.8 & 256.2 \\
\hline $\mathrm{Cl}_{\text {type }}$ & 5.6 & 2107.8 & 129.3 & 27.6 & 178.2 & 3256.5 & 187.4 & 1104.8 \\
\hline $\mathrm{Cl}_{\text {type }}$ & 9.8 & 3500.0 & 120.0 & 58.0 & 540.0 & 4704.0 & 1166.0 & 336.3 \\
\hline $\mathrm{Cl}_{\text {type }}$ & 3.3 & 2829.0 & 154.4 & 25.0 & 173.8 & 4078.6 & 232.8 & 628.3 \\
\hline $\mathrm{SO}_{4} \sim 100 \%$ & 0.0 & 64.0 & 12.0 & 8.1 & 220.0 & 2.8 & 736.8 & 0.0 \\
\hline $\mathrm{SO}_{4}$ type & 0.3 & 333.3 & 33.9 & 86.0 & 269.6 & 294.7 & 1039.2 & 287.9 \\
\hline $\mathrm{SO}_{4}$ type & 0.3 & 300.0 & 32.0 & 79.0 & 250.0 & 265.6 & 1005.0 & 106.9 \\
\hline $\mathrm{SO}_{4} \sim 100 \%$ & 0.0 & 14.0 & 4.6 & 8.2 & 45.0 & 2.0 & 263.4 & 0.0 \\
\hline $\mathrm{SO}_{4}$ type & 0.7 & 112.0 & 11.7 & 35.2 & 92.8 & 99.0 & 373.9 & 141.5 \\
\hline $\mathrm{SO}_{4}$ type & 0.1 & 67.0 & 13.0 & 36.0 & 65.0 & 79.5 & 340.8 & 14.3 \\
\hline $\mathrm{HCO}_{3}$ type & - & 5.1 & 1.5 & 0.4 & 4.0 & 1.9 & 10.6 & 17.1 \\
\hline $\mathrm{SO}_{4}$ type & - & 29.7 & 3.3 & 19.4 & 44.4 & 44.0 & 150.2 & 65.3 \\
\hline $\mathrm{SO}_{4}$ type & 0.0 & 7.2 & 3.7 & 4.1 & 25.0 & 5.5 & 50.6 & 22.6 \\
\hline $\mathrm{SO}_{4}$ type & - & 27.8 & 2.7 & 16.6 & 38.2 & 29.5 & 113.8 & 59.8 \\
\hline $\mathrm{SO}_{4}$ type & - & 19.6 & 3.2 & 11.4 & 42.6 & 28.4 & 93.6 & 91.5 \\
\hline $\mathrm{SO}_{4}$ type & - & 18.4 & 4.7 & 15.7 & 42.0 & 22.7 & 118.1 & 72.0 \\
\hline $\mathrm{HCO}_{3}$ type & - & 6.4 & 2.3 & 2.6 & 14.0 & 2.3 & 27.8 & 36.6 \\
\hline & & & & & & & & \\
\hline
\end{tabular}

of substantial hydrothermal alteration inside the landslide scar on the southern flank is consistent with such $\mathrm{N}-\mathrm{S}$ elongated hydrothermal system.

\subsubsection{AMT (resistivity cross-section)}

Fig. 4 shows the AMT resistivity section and the SP profile along the same path on the western flank of the edifice. Because the data

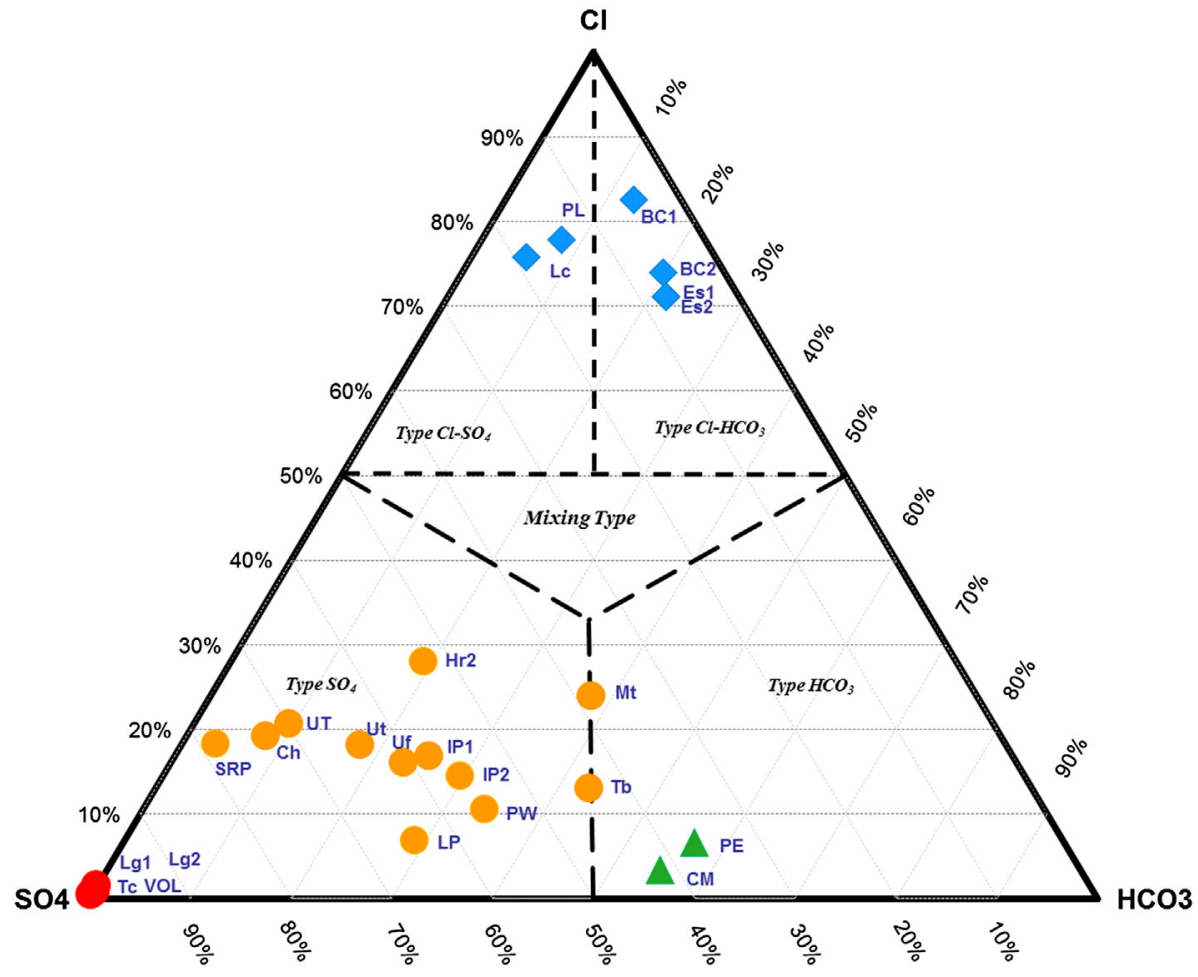

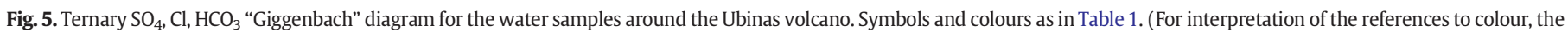
reader is referred to the web version of this article.) 

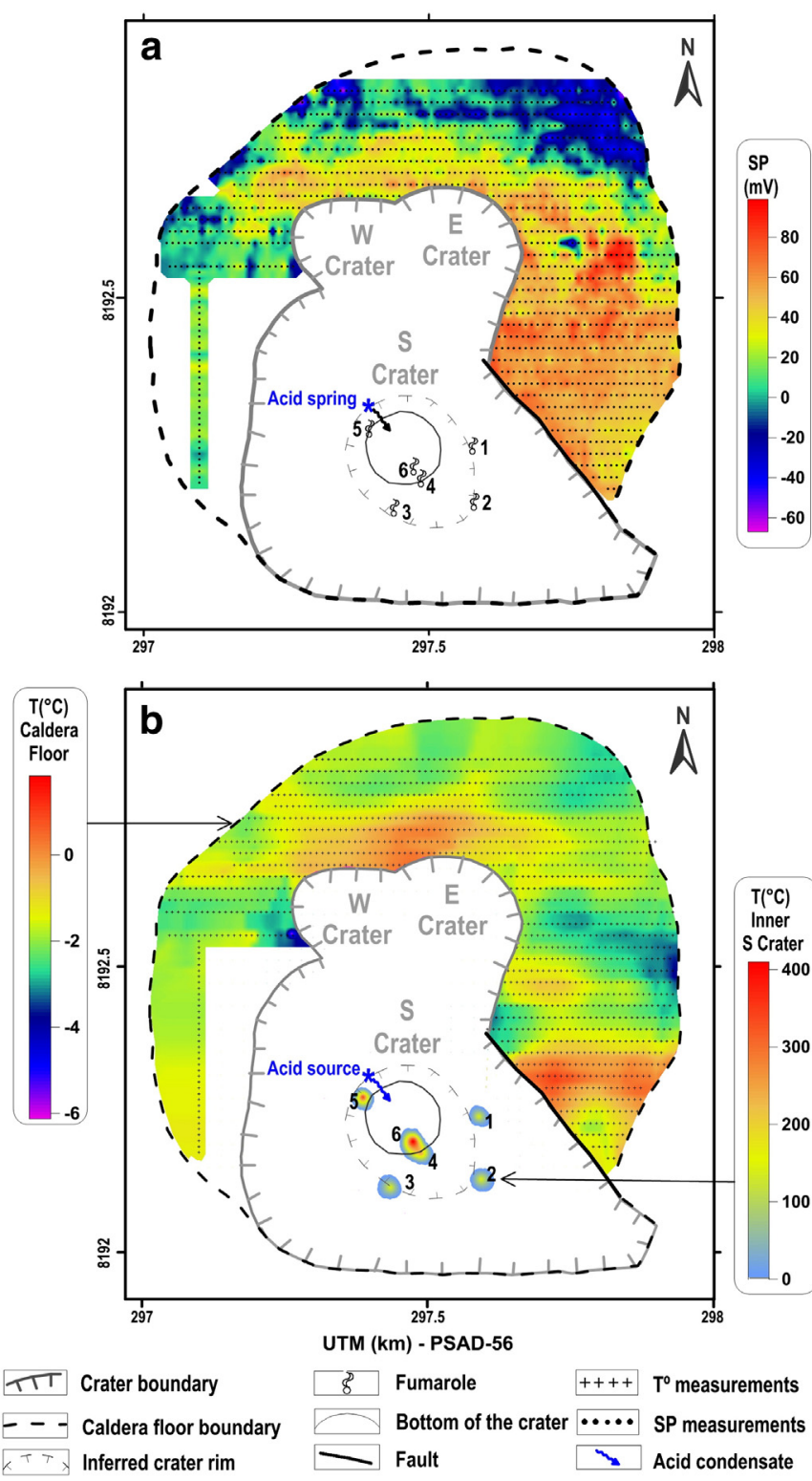

Fig. 6. a. Self-potential map of the floor of the summit caldera of Ubinas. b. Temperature map at $20 \mathrm{~cm}$ in depth on the floor of the summit caldera of Ubinas.

modelling tends to smooth the overall distribution of resistivity values, sharper resistivity contrasts may exist but they may not be pictured by the processing method. However, the large-scale resistivity patterns are well constrained and significant lateral and vertical variations appear in the resistivity section along the profile (such as the vertical variation between AMT soundings 13 and 14 in Fig. 4). The resistivity of rocks is controlled by various factors among which the water content, its temperature and mineralization, and the presence of clays minerals are the most important (e.g. Keller (1988), Palacky (1988), Kauahikaua (1993), and Lénat (1995)). In a volcanic setting, the layers with high resistivity (from about 100 to over $5000 \Omega \cdot \mathrm{m}$ ) are typically unsaturated or fresh-water saturated volcanic formations. The layers with low resistivity values $(<20 \Omega \cdot \mathrm{m})$ are formations saturated by hot fluids and/or hydrothermally altered forming clay-rich rocks. AMT soundings are not available in the summit area, where the presence of shallow conductive layers would be expected, owing to the intense surface hydrothermal activity in the summit S pit crater (Fig. 2b). However, the soundings near the crater rim (13,14 and 15 in Fig. 4) unambiguously show a rise of a conductor in this area up to $\sim 5100 \mathrm{~m}$ asl. This elevation is approximately that of the fumaroles inside the summit $\mathrm{S}$ pit crater
(Fig. 2b). The most likely source of the observed low resistivity values in this area is therefore the conductive hydrated minerals, such as clay minerals or zeolites, deriving from hydrothermal alteration and mineralization of hydrothermal fluids. The boundary between the summit conductor and the resistive lower flank is sharply defined in the model. This strongly suggests that a fault and/or lithologic contrast may control the lateral extent of the hydrothermal system. The SP minimum, usually explained by the transition from hydrogeological to hydrothermal conditions, does not coincide with the shallow lateral resistivity contrast. Between the SP minimum and the latter, we observe a thick resistive sequence, about 1000-1200 m wide. In addition, the resistive flank sequence appears to thicken downward to the east of the SP minimum. If the deepening of the resistive-conductive interface corresponded to a deepening of the water table, as observed close to the valley rim, we would expect the SP signal to become more negative because the vadose zone would be thicker. Therefore, this transition zone is not fully explained with the available data.

The lower flank of the volcano is made of resistive rocks. Beneath these resistive layers, conductive rocks are present. The nature of the conductive part of the substratum $(<10 \Omega \cdot \mathrm{m})$ is difficult to assess: it may tentatively be attributed to the lateral invasion of the medium by the volcano hydrothermal fluids. At the foot of the volcano, a thin resistive layer, hardly resolved in the model, may also suggest the presence of a vadose zone perched above a shallow water table.

\subsubsection{Water springs around Ubinas}

Water springs around Ubinas edifice clearly display a distribution skewed towards the east side of the edifice, on Ubinas and Rio Tambo valleys side (Table 1 ). Average temperature of the water springs range from 8.0 to $40.6{ }^{\circ} \mathrm{C}$. These latter are often associated with faults, as shown in Fig. 8. The geochemical analysis of the springs water shows three types of spring water (Table 1 and Fig. 5): (1) $\mathrm{SO}_{4}$ 100\%-type (red colour in Fig. 5), (2) $\mathrm{SO}_{4}$-type (orange colour in Fig. 5), and (3) Cl-type (blue colour in Fig. 5). The $\mathrm{SO}_{4} \sim 100 \%$-type water are all located more than $10 \mathrm{~km}$ southwest of the Ubinas summit, and is thought to reflect another magmatic contribution than the Ubinas edifice. $\mathrm{SO}_{4}$-type springs are located to the east base of the edifice (see SRP, Uf, Ut and CH springs in Fig. 8) and also to the south base (PW, IP1, IP2, Tb, PW springs in Fig. 8). These hot springs with temperatures $>15{ }^{\circ} \mathrm{C}$ are located to the southeast side, where a preferential interaction (through faults) of meteoric water with hot hydrothermal fluid flow occur at depth towards the Ubinas valley. Cl-type springs located in the northeast side of Ubinas edifice and are clearly related to another system, with poor or no interactions with the Ubinas magmatic/hydrothermal fluids (Fig. 8).

\subsection{Across the summit caldera}

\subsubsection{SP and thermal anomalies}

The SP map shows low-amplitude variations only on the caldera floor. The values vary from $-67 \mathrm{mV}$ to $+99 \mathrm{mV}$ (note the range in the colour scale in Fig. 5). The highest SP values are observed in the east part of the caldera, between the east rims of $\mathrm{E}$ and $\mathrm{S}$ craters and the caldera rim to the east (Figs. 2a and 5). Lower values are located farther from the fumaroles of S crater, in the north part of caldera floor. Similarly, the temperature map (Fig. 6) does not show any significant anomaly on the caldera floor, with values ranging from -9 to $+4{ }^{\circ} \mathrm{C}$.

These observations are quite surprising because one may expect higher SP and temperature anomalies near the summit active zone. The large degassing and the extremely high temperatures observed in the $\mathrm{S}$ crater (maximum of $444{ }^{\circ} \mathrm{C}$ measured on fumarole 6) clearly indicate the presence of a sustained and active shallow hydrothermal system beneath the summit. Such phenomenon is also confirmed by the shallow seismicity observed during quiescent degassing period (Inza et al., 2011). The virtual absence of SP and temperature anomalies on 


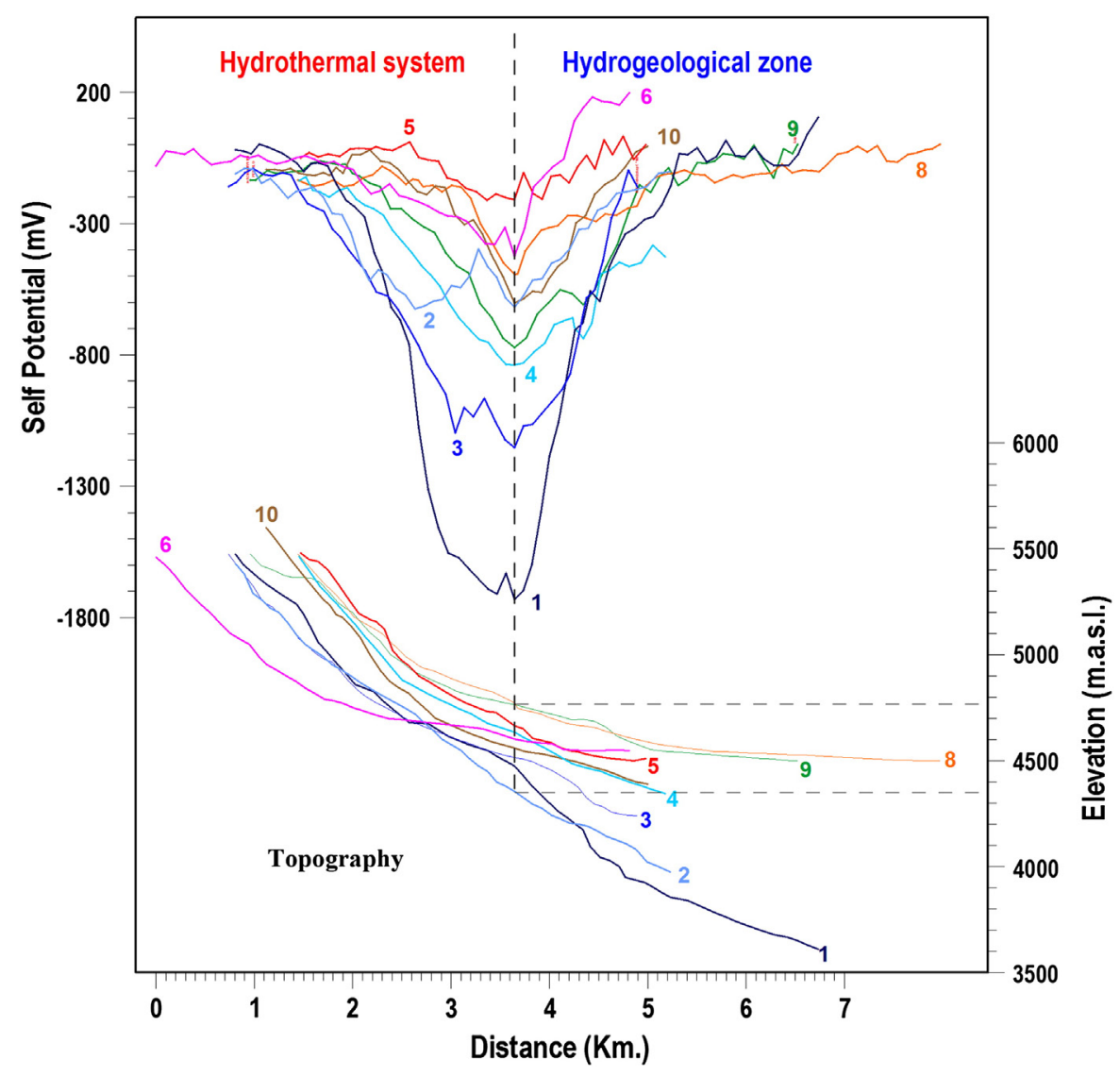

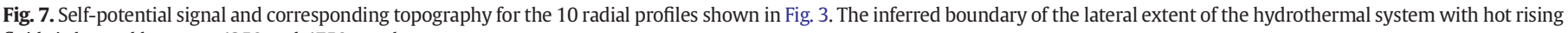
fluids is located between 4350 and $4750 \mathrm{~m}$ asl.

the caldera floor therefore requires a specific geological explanation, as discussed below.

\section{Discussion}

\subsection{Structure of the volcanic cone}

From all perspectives, whether morphological (Fig. 1b), geological (Thouret et al., 2005) or from our SP results, Ubinas volcano is a highly asymmetric edifice straddling a high plateau and the slope of the deep Ubinas valley. The contrast between the west and east flanks is well-illustrated by the SP map (Fig. 3), which exhibits a huge difference (several hundred of $\mathrm{mV}$ ) in the amplitude of the SP anomaly between the two flanks. The separation between the two parts broadly coincides with the continuation of the rim of the valley beneath the edifice (Figs. 3 and 8).

Because we acquired both SP and resistivity data on the west flank, we first begin with the analysis of the structure of the edifice in this area. Near the summit, the obvious feature is the sharp lateral transition between conductive terrains beneath the summit and resistive areas on the flank (Fig. 4). This pattern implies a rapid lateral variation of lithology, which would be best explained by the presence of a fault. Here a fault is likely to be a collapse scarp potentially associated with the "Ubinas Cone 1" caldera (Thouret et al., 2005). The products filling the caldera may have a more conductive nature than the pile of lava flows of the flank. In addition, the resistivity of the infilling products may have been lowered by hydrothermal alteration. In this case, the hydrothermal system would have been confined toward the west by the collapse fault. The top of the conductor virtually coincides with the elevation of the bottom of the inner crater of the present-day caldera where intense hydrothermal manifestations are observed (see Geological setting above). By contrast, the floor of the caldera is devoid of any surficial hydrothermal manifestation and, instead, exhibits nearly flat temperature and SP signals. Flat SP signals are not unexpected around hydrothermal active summit craters (Aizawa et al., 2009). This pattern, observed at the summit of an active volcano with hydrothermal activity, indicates that the fluids are confined at depth by a shallow impermeable layer. We propose, as shown in Fig. 9, that a low permeability layer may have developed above the hydrothermal system by self-sealing. This has been observed at other volcanoes, such as in Soufriere Saint Vincent (Fournier et al., 2011), Galeras (Stix et al., 1993; Fischer et al., 1996) and Japanese volcanoes (Aizawa et al., 2009) and is consistent with the absence of hot springs around most of the edifice at Ubinas. The exception is where the Ubinas edifice is intersected by regional faults, hence providing a potential pathway for hydrothermal fluids. The inner S Crater cut this layer and acts as a pressure-release "valve" for the underlying hydrothermal system.

The lower flank of the edifice is characterised by resistive rocks that can be readily identified as the pile of thick lava flows found in this part of the cone (Thouret et al., 2005). Fig. 4 shows that the rocks of the basement under the edifice are more conductive. They even become highly conductive $(<20 \Omega \cdot \mathrm{m})$ at depths of a few hundreds of metres beneath the lower flank and beyond. According to Thouret et al. (2005), the basement of the current Ubinas volcano consists mostly of lava flows, with a minor proportion of pyroclastic deposits and sediments. When saturated with meteoric water (i.e. beneath the water table), such rocks may show resistivity values between about $100(\Omega \cdot \mathrm{m})$ to $1000-2000 \Omega \cdot \mathrm{m}$. However, explaining resistivity values as low as $20 \Omega \cdot \mathrm{m}$ or less requires the presence of a significant amount of highly conductive minerals, such as clays, or the presence of hydrothermal fluids. Although we cannot determine which of the two possible causes prevails here with the available data, we suggest (Fig. 9) that the rocks 


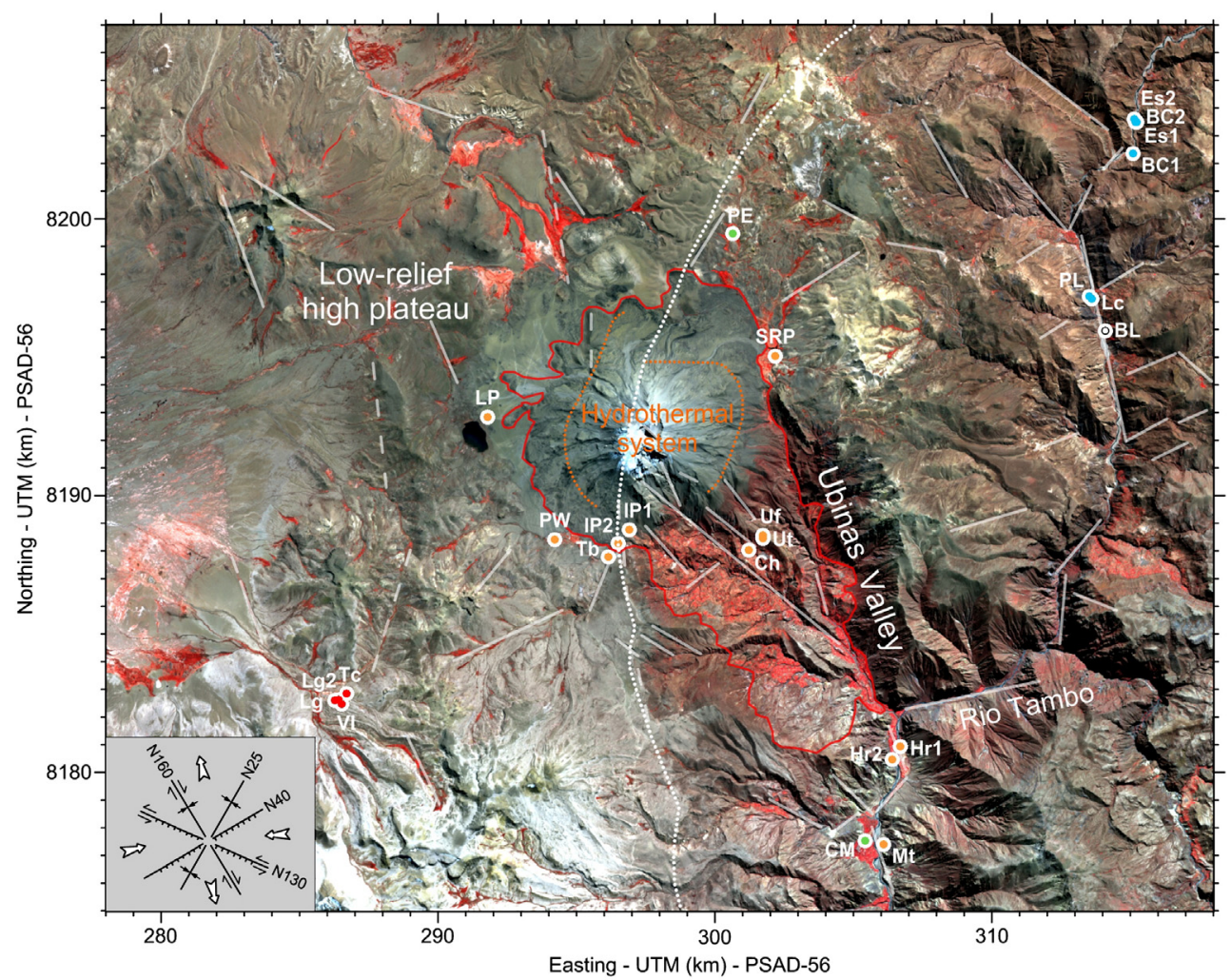

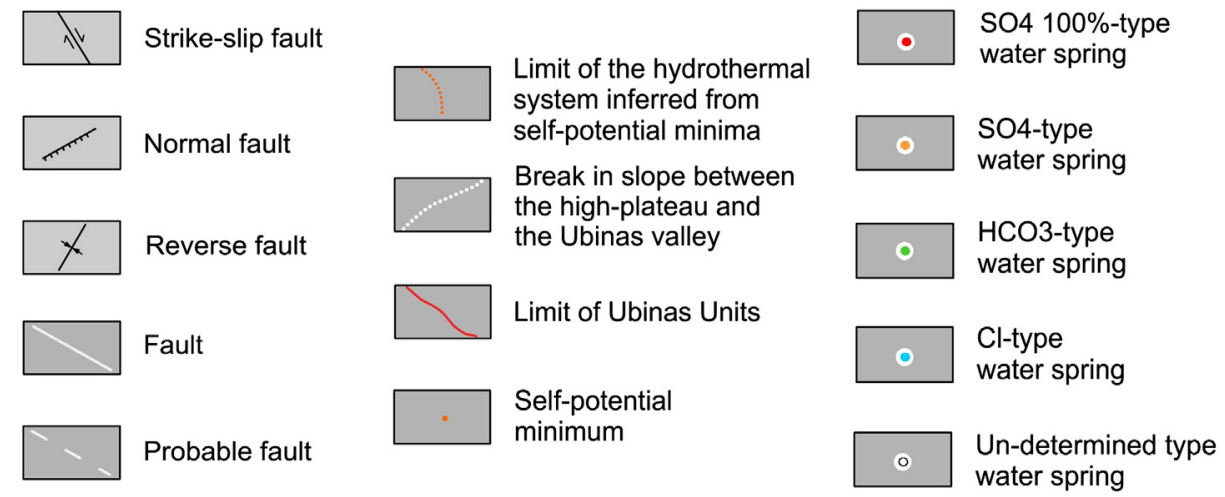

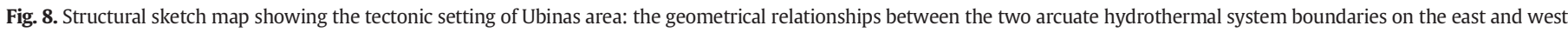

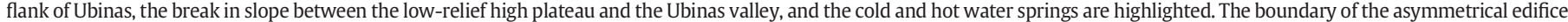

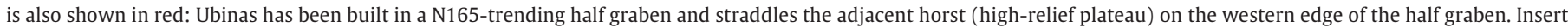

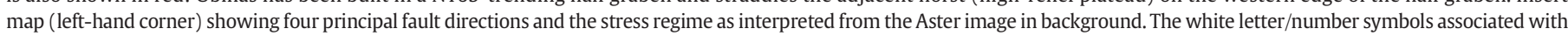
the location of each water spring are related to Table 1. (For interpretation of the references to colour in this figure legend, the reader is referred to the web version of this article.)

of the basement are contaminated by hydrothermal fluids flowing laterally from the central hydrothermal system, following preferential paths along faults in the case of the east side. Similar observations have been made at other volcanic sites (e.g. Finizola et al., 2010; Byrdina et al., 2013) and, on the east flank of the Ubinas volcano, the thermal springs observed at the base of the edifice, at the bottom of Ubinas valleys, have probably a similar origin. Considering the chemical components, Cruz et al. (2009) believe that, locally mixing between meteoric water and hydrothermal fluids may occur in the Ubinas Termal, Ubinas Fría and Chiflón springs (see Table 1, Fig. 8). Mixing occurring at depth (water table level) is favoured by the presence of faults.

The correlation between the SP and surficial/shallow resistivity pattern on the western flank (Figs. 4 and 9) is not straightforward. The SP minimum is usually interpreted as the limit between a zone dominated by the downward flow of meteoric water and a zone dominated by the upward flow of hydrothermal fluids. Accordingly, the SP minimum also usually coincides with a lateral variation of resistivity, because the hydrothermal alteration lowers the resistivity of the rocks. Following this scheme, we would expect the low SP to coincide with the sharp resistivity contrast observed in the upper part of the flank. It is not the case as the SP minimum is offset by nearly $1 \mathrm{~km}$ to the west of the boundary of the central conductive structure. This apparent discrepancy could be partially explained by the contrast of resistivity between the resistive pile of lava flows and the more conductive rocks that surround it. SP signals are larger over resistive zones than over conductive ones because of the effect of the resistivity on the pattern of the electric fields (Aizawa, 2008). Fig. 4 shows that the amplitude of the SP signal is indeed larger above the resistive zone. However, if this resistivity contrast changes the amplitude of the SP signal, it probably does not change the location of the minimum. The alternative explanation for the offset between the SP minimum and the conductive body beneath the summit is that the hydrothermal system now extends over a larger area than that of the conductive body and at a greater depth. 


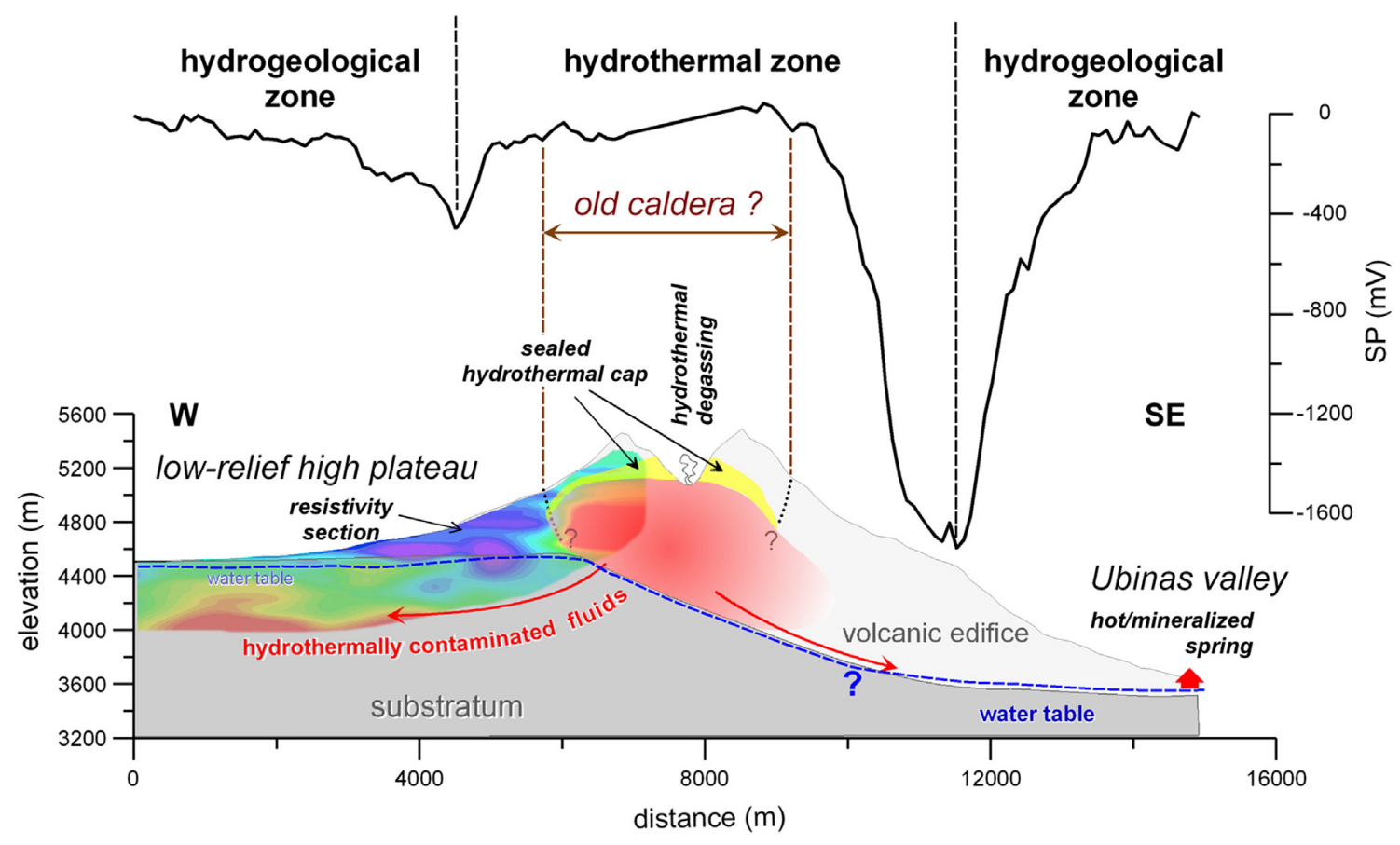

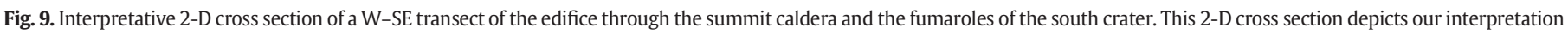
of the Ubinas structure.

The deposits that form the east flank are significantly thicker than the west ones, because the volcano base lies at lower elevations in the Ubinas valley (Figs. 1B and 9). The SP pattern of the east flank is similar to the one of the west flank, but with a huge difference: the amplitude of the minimum is fivefold that of the west flank (Figs. 3 and 9). In terms of hydrogeology, this difference is usually interpreted by a difference in the depth of the water table, provided that the rocks characteristics are not too different between the two zones (a reasonable assumption in the case of Ubinas volcano). Indeed, as shown in Fig. 9, a large difference in thickness of the vadose zone is expected between the west and east flanks, and the water table lies presumably deeper on the east flank. An alternative hypothesis can be found in Byrdina et al. (2013) or Revil et al. (2008) who explain the observed SP anomaly rather through the flow below the water table than in terms of thickness of the vadose zone.

In SP terms, the east flank can also be divided into hydrogeological and hydrothermal zones. However, we can presume that the large difference in scale of the SP with the west flank may mirror the size of the internal structures. In particular, the extent of the hydrothermal system may be greater downslope, because of the larger gravitational flow potential of hydrothermal fluids. As Byrdina et al. (2013) have shown in the case of the Tiscani complex, the topography of the basement may play a crucial role in the location and extent of a hydrothermal system through the gravitational flows of the hydrothermal fluids. At Ubinas volcano, hot springs are observed in the valley at the foot of the edifice, similar to what Byrdina et al. (2013) have observed in the valleys around the Ticsani complex. This is a strong indication that the east flank of the Ubinas volcano may be altered by hydrothermal activity. The location of $\mathrm{SO}_{4}$-type springs to the north and south indicates two preferential paths for fluid flows; (1) along the break in slope located between the low relief high plateau and the Ubinas valley, and (2) along tectonic faults with preferential NW-SE direction.

In map view, the arcuate SP minimum of the two flanks do not connect to the north (Fig. 8). This zone of no apparent continuity of the SP minimum seems to correlate with the break in slope between the high plateau and the Ubinas valley (Fig. 8). To the north, neither data (e.g. resistivity) nor observations (hydrothermally altered rocks, or fumaroles) are available to us. To the south, however, the landslide has exposed hydrothermally altered rocks the presence of which enables us to argue that the hydrothermal system extends slightly within the south flank.

Another evidence of the hydrothermal system within the south flank can be found in the work of Inza et al. (2014). Based on the analysis of seismic signals related to 16 vulcanian explosions occurred during the 2009 eruptive crisis, the authors indicate that the epicentres of explosions in central conduit and associated deeper LP events are located slightly southward of the volcanic edifice, under the south crater. As a consequence, the extension of the hydrothermal system seems to affect also, at least, the upper south flank.

In our survey, the hydrothermal system studied with SP method displays a striking result, with an atypical shape of the SP minimum toward the north, while the extent of the hydrothermal system is much larger (about $2 \mathrm{~km}$ ) on the west than on the east flank. This indicates clearly a change in the heat propagation (conductive and/or convective transfer) between the west and east flanks, and precisely between the profiles 5 and 6 (see Fig. 3). The presence of the sharp break in slope between the high-plateau and the Ubinas valley located just between both profiles 5 and 6 suggests an influence in the heat propagation by this topographic feature.

Apparently the west flank better conduce a heat source than the east flank. The most evident interpretation is to consider that the geometry of the basement play a major role in controlling the geometry of the hydrothermal system at Ubinas volcano.

In summary, Ubinas appears as a heterogeneous volcano comprising two different parts. (1) The west flank displays a relatively simple and commonly found pattern of alternating hydrogeologic and hydrothermal zones. (2) The east flank differs in the fact that it is built on the steep side of a deep valley and is therefore significantly thicker. In this case, the resulting large altitude difference between the summit and the base of the east flank may result in a larger extent of the hydrothermal system on that side of the edifice.

\subsection{Role of asymmetrical basement topography on composite volcanoes in} south Peru

Another Peruvian volcano also shows large topography variations and SP anomalies similar to that of the Ubinas volcano: El Misti, located 
$70 \mathrm{~km} \mathrm{~W}$ of Ubinas (Finizola et al., 2004; Tort and Finizola, 2005). The morphology (or the construction) of El Misti volcano is spectacular with its northeast half built up on a high plateau and the southwest part built on the slope of the Western Cordillera between the high plateau and the Arequipa basin (Fig. 10). The SP map of El Misti volcano shows similar patterns with the Ubinas SP map, with large SP minimum (up to $4 \mathrm{~V}$ of amplitude) within the SW flank. The SP low shows the largest amplitude on the W-SW flank. Similarly, the central hydrothermal zone is elongated in the same direction as the rim of the low-relief high plateau (profile no. 1 of Fig. 2 in Finizola et al., 2004). The comparison with the results obtained by Byrdina et al. (2013) on Ticsani volcano reveals that the slope of the basement on which a volcano has grown plays a major role in the geometry of the hydrothermal systems: the gravitational flow of hydrothermal fluids will tend to extend the hydrothermalized zone downslope. As a result, the flanks built on the slope will be thicker and more hydrothermally altered than the flanks built on plateaus, a feature (or a process) which lead to spreading or even a potential collapse.

\subsection{Implications on volcanic hazards}

Understanding potential destabilising conditions and processes that trigger volcano flank collapses is a critical issue when we must assess volcano hazards on composite volcanoes surrounded by densely populated areas in the Andes. In the case of the Ubinas volcano, the geological setting, the presence of older sector collapse and recent flank failure episodes, as well as the extent of the hydrothermal system extended downslope towards the south increase the probability of the collapse flank occurrence.
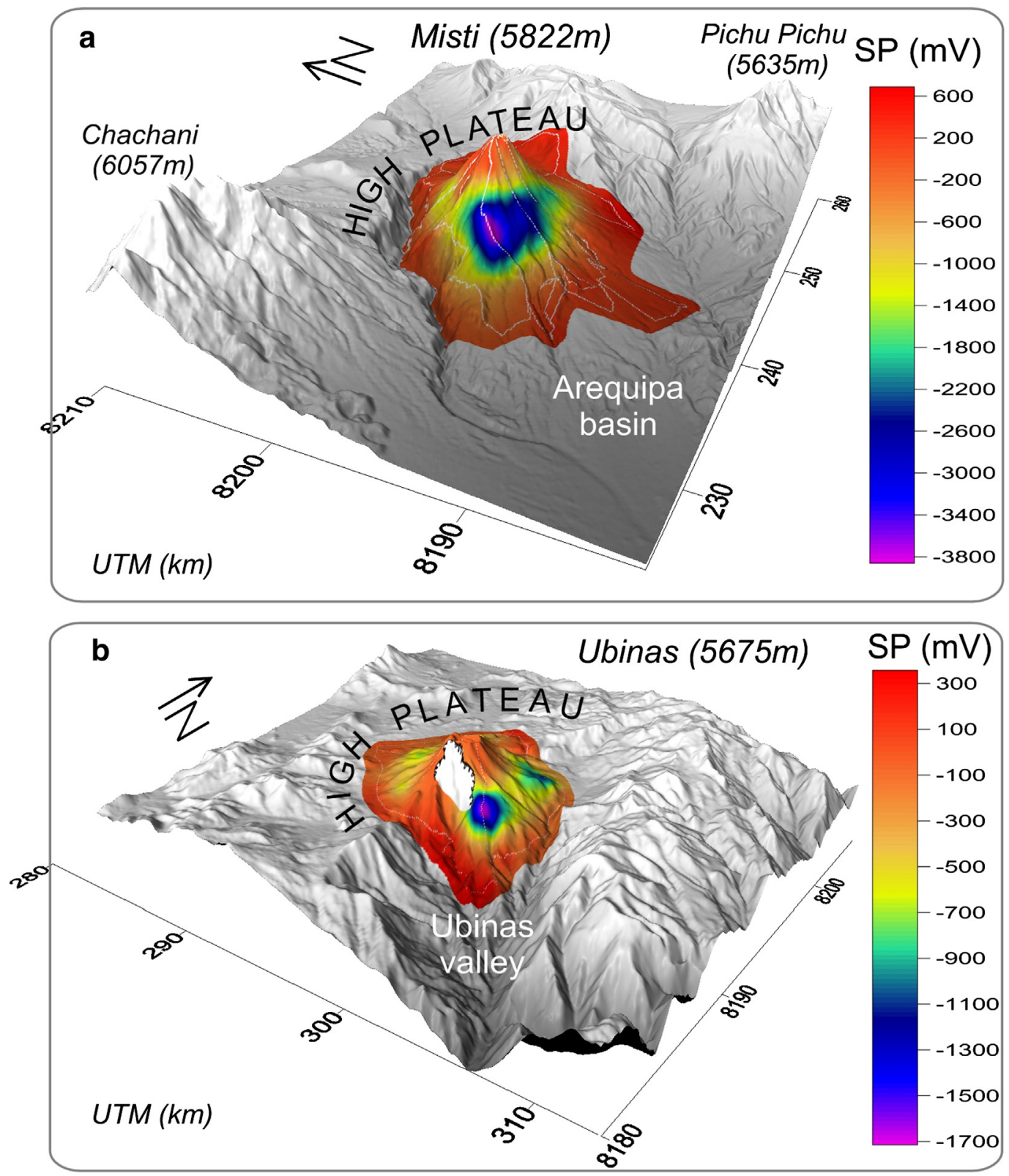

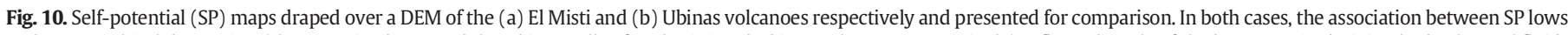

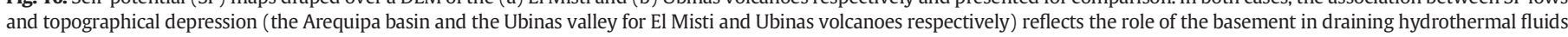
and weakening volcanic edifices in an asymmetrical way (see text for explanation). 
As shown earlier on other volcanoes (Lopez and Williams, 1993; Reid, 2004) the presence of hydrothermally altered rocks in the edifice can lead to hydrothermally-driven, massive edifice collapses. Other deep-seated collapses have occurred without magmatic eruption and lack of juvenile eruptive products (such as Bandai-San, Siebert et al., 1987) but these flank failures are unlikely to be directly triggered by magma intrusion into an edifice (Reid, 2004). Both scenarios may happen at Ubinas volcano. The first one can be supported by the present day vertical and unstable south wall where highly hydrothermalized rocks are observed together with the presence of Holocene debris avalanches deposits down the Ubinas valley (Thouret et al., 2005). The second scenario is based on the existence of a partially hydrothermally altered southeast flank as proposed in our model, and reactivating a possible sliding plane like the steep basement topography (Fig. 8). For this second model, new visible fractures at the surface reactivating former faults have been evidenced on two active volcanoes during their recent eruptive crises; new fractures in the Fossa area on Stromboli volcano during the 2002-2003 eruption (Finizola et al., 2009) and new Dolomieu caldera collapse boundaries on Piton de la Fournaise volcano during the 2007 eruption (Barde-Cabusson et al., 2012).

\section{Conclusions}

Based on the SP survey performed at the scale of the entire Ubinas edifice, a strong structural asymmetry, which has effects on the hydrothermal system, has been evidenced between the west and the east flank. AMT, summit caldera floor SP and temperature mapping all display the roof of the hydrothermal system that intersects the bottom of the south crater at about $5100 \mathrm{~m}$ asl.

This study stresses the role of sloping basement under volcanoes and how much the topography may exert a control on the lateral development of hydrothermal systems. In the case of the Ubinas and El Misti volcanoes, SP mapping has provided a clear image of the asymmetry of these composite edifices. As shown by Byrdina et al. (2013), the gravitational flow of the hydrothermal fluids along the slope tends to deform and elongate the hydrothermal system downslope. As a result, the flanks which are the result of a thick pile of deposits will tend to become unstable due to: (1) a thick accumulation of volcanic deposits and (2) a large volume of low cohesion, hydrothermally altered rocks (Cecchi et al., 2004; Reid, 2004). Consequently, the bulk of composite volcanoes built on steep basement will have a high potential of spreading and sliding along the slope. Ultimately, this implies that improving our knowledge of the basement geometry and extent of hydrothermal system may improve further hazard assessments for slope stability and potential large flank collapses at composite volcanoes.

\section{Acknowledgements}

Geophysical surveys were funded by the Instituto Geofísico del Perú (IGP) and the Institut de Recherche pour le Développement (IRD). We thank R. Pinto, P. Navarro, J. Taco, M. Uribe, V. Montesinos and the inhabitants of Ubinas village for field assistance. We thank IGP and Cooperation Office of the French Embassy that supported scientific exchanges between institutions. We thank Koki Aizawa and André Revil for the constructive reviews of our manuscript.

\section{Appendix A. Supplementary data}

Supplementary data to this article can be found online at http://dx. doi.org/10.1016/j.jvolgeores.2014.02.020.

\section{References}

Aizawa, K., 2004. A large self-potential anomaly and its changes on the quiet Mt. Fuji, Japan. Geophys. Res. Lett. 31, L05612. http://dx.doi.org/10.1029/2004GL019462.
Aizawa, K., 2008. Classification of self-potential anomalies on volcanoes and possible interpretations for their subsurface structure. J. Volcanol. Geotherm. Res. 175 (2008), 253-268. http://dx.doi.org/10.1016/j.jvolgeores.2008.03.011.

Aizawa, K., Uyeshima, M., Nogami, K., 2008. Zeta potential estimation of volcanic rocks on 11 island arc-type volcanoes in Japan: Implication for the generation of local self-potential anomalies. Journal of Geophysical Research 113. http://dx.doi.org/10.1029/ 2007JB005058 (issn: 0148-0227).

Aizawa, K., Ogawa, Y., Ishido, T., 2009. Groundwater flow and hydrothermal systems within volcanic edifices: delineation by electric self-potential and magnetotellurics. J. Geophys. Res. 114. http://dx.doi.org/10.1029/2008jb005910.

Aubert, M., Atangana, Q., 1996. Self-potential method in hydrogeological exploration of volcanic areas. Ground Water 34 (6), 1010-1016.

Aubert, M., Antraygues, P., Soler, E., 1993. Interpretation of the self-potential measurements in hydrogeological exploration of a volcanic massif. On the existence of groundwater flow paths on the south flank of the Piton de la Fournaise (Réunion Island). Bull. Soc. Géol. Fr. 164, 17-25.

Aubert, M., Dana, I.N., Gourgaud, A., 2000. Internal structure of the Merapi summit from self-potential measurements. J. Volcanol. Geotherm. Res. 100, 337-343.

Aubert, M., Diliberto, S., Finizola, A., Chébli, Y., 2007. Double origin of hydrothermal convective flux variations in the Fossa of Vulcano (Italy). Bull. Volcanol. 70, 743-751. http://dx.doi.org/10.1007/s00445-007-0165-y.

Avena, M.J., De Pauli, C.P., 1996. Modeling the interfacial properties of an amorphous aluminosilicate dispersed in aqueous $\mathrm{NaCl}$ solutions. Colloids Surf. 118, 75-87.

Barde-Cabusson, S., Finizola, A., Revil, A., Ricci, T., Piscitelli, S., Rizzo, E., Angeletti, B., Balasco, M., Bennati, L., Byrdina, S., Carzaniga, N., Crespy, A., Di Gangi, F., Morin, J., Perrone, A., Rossi, M., Roulleau, E., Suski, B., Villeneuve, N., 2009a. New geological insights and structural control on fluid circulation in La Fossa cone (Vulcano, Aeolian Islands, Italy). J. Volcanol. Geotherm. Res. 185, 231-245. http://dx.doi.org/10.1016/j. jvolgeores.2009.06.002.

Barde-Cabusson, S., Levieux, G., Lénat, J.-F., Finizola, A., Revil, A., Chaput, M., Dumont, S., Duputel, Z., Guy, A., Mathieu, L., Saumet, S., Sorbadère, F., Vieille, M., 2009b. Transient self-potential anomalies associated with recent lava flows at Piton de la Fournaise volcano (Réunion Island, Indian Ocean). J. Volcanol. Geotherm. Res. 187, 158-166. http://dx.doi.org/10.1016/j.jvolgeores.2009.09.003.

Barde-Cabusson, S., Finizola, A., Peltier, A., Chaput, M., Taquet, N., Dumont, S., Duputel, Z., Guy, A., Mathieu, L., Saumet, S., Sorbadère, F., Vieille, M., 2012. Structural control of collapse events inferred by self-potential mapping on the Piton de la Fournaise volcano (La Réunion Island). J. Volcanol. Geotherm. Res. 209-210, 9-18. http://dx.doi.org/ 10.1016/j.jvolgeores.2011.09.014.

Bennati, L., Finizola, A., Walker, J., Lopez, D., Higuiera-Diaz, C., Schütze, C., Barahona, F., Cartagena, R., Conde, V., Funes, R., Rios, C., 2011. Fluid circulation in a complex volcano-tectonic setting, inferred from self-potential and soil $\mathrm{CO}_{2}$ flux surveys: the Santa María-Cerro Quemado-Zunil volcanoes and Xela caldera (northwestern Guatemala). J. Volcanol. Geotherm. Res. 199, 216-229. http://dx.doi.org/10.1016/j. jvolgeores.2010.11.008.

Bostick Jr., F.X., 1977. A simple almost exact method of MT analysis: workshop on electrical methods in geothermal exploration. US Geol. Surv. 174-183.

Boubekraoui, S., Courteaud, M., Aubert, M., Albouy, Y., Coudray, J., 1998. New insights into the hydrogeology of a basaltic shield volcano from a comparison between selfpotential and electromagnetic data: Piton de la Fournaise, Indian Ocean. J. Appl. Geophys. 40, 165-177.

Byrdina, S., Ramos, D., Vandemeulebrouck, J., Masias, P., Revil, A., Finizola, A., Gonzales, Zuñiga K., Cruz, V., Antayhua, Y., Macedo, O., 2013. Influence of the regional topography on the remote emplacement of hydrothermal systems with examples of Ticsani and Ubinas volcanoes Southern Peru. Earth Planet. Sci. Lett. 365, 152-164. http://dx. doi.org/10.1016/j.epsl.2013.01.018.

Cecchi, E., van Wyk de Vries, B. Lavest, J.-M., 2004. Flank spreading and collapse of weakcored volcanoes. Bull. Volcanol. 67 (1), 72-91. http://dx.doi.org/10.1007/s00445004-0369-3.

Constable, S.C., Parker, R.L., Constable, C.G., 1987. Occam's inversion - a practical algorithm for generating smooth models from electromagnetic sounding data. Geophysics 52, 289-300. http://dx.doi.org/10.1190/1.1442303.

Corwin, R.F., Hoover, D.B., 1979. The self-potential method in geothermal exploration. Geophysics 44-2, 226-245.

Cruz, V., Gonzales, K., Macedo, O., Fournier, N., 2009. Caracterización geoquímica de las fuentes termales y frías asociadas al volcán Ubinas en el sur del Perú. Bol. Soc. Geol. Peru. 103, 265-281.

De Silva, V., Francis, P., 1991. Volcanoes of the Central AndesSpringer, Berlin (216 pp.).

Dobrin, M.B., Savit, C.H., 1988. Introduction to Geophysical ProspectingMcGraw-Hill Book Co., New York (867 pp.)

Finizola, A, Sortino, F, Lénat, J.-F., Valenza, M, 2002. Fluid circulation at Stromboli volcano, (Aeolian Island, Italy) from self-potential and $\mathrm{CO}_{2}$ surveys. J. Volcanol. Geotherm. Res. 116 (1-2), 1-18.

Finizola, A., Sortino, F., Lénat, J.-F., Aubert, M., Ripepe, M., Valenza, M., 2003. The summit hydrothermal system of Stromboli: new insights from self-potential, temperature, $\mathrm{CO}_{2}$ and fumarolic fluids measurements, with structural and monitoring implications. Bull. Volcanol. 65, 486-504. http://dx.doi.org/10.1007/ s00445-003-0276-2.

Finizola, A., Lénat, J.F., Macedo, O., Ramos, D., Thouret, J.-C., Sortino, F., 2004. Fluid circulation and structural discontinuities inside Misti volcano (Peru) inferred from selfpotential measurements. J. Volcanol. Geotherm. Res. 135, 343-360. http://dx.doi. org/10.1016/j.jvolgeores.2004.03.009.

Finizola, A., Revil, A., Rizzo, E., Piscitelli, S., Ricci, T., Morin, J., Angeletti, B., Mocochain, L., Sortino, F., 2006. Hydrogeological insights at Stromboli volcano (Italy) from geoelectrical, temperature, and $\mathrm{CO}_{2}$ soil degassing investigations. Geophys. Res. Lett. 33, L17304. http://dx.doi.org/10.1029/2006GL026842. 
Finizola, A., Aubert, M., Revil, A., Schütze, C., Sortino, F., 2009. Importance of structural history in the summit area of Stromboli during the 2002-2003 eruptive crisis inferred from temperature, soil $\mathrm{CO}_{2}$, self-potential, and electrical resistivity tomography.J.Volcanol. Geotherm. Res. 183, 213-227. http://dx.doi.org/10.1016/j.jvolgeores.2009.04.002.

Finizola, A., Ricci, T., Deiana, R., Barde-Cabusson, S., Rossi, M., Praticelli, N., Giocoli, A., Romano, G., Delcher, E., Suski, B., Revil, A., Menny, P., Di Gangi, F., Letort, J., Peltier, A., VillasanteMarcos, V., Douillet, G., Avard, G., Lelli, M., 2010. Adventive hydrothermal circulation on Stromboli volcano (Aeolian Islands, Italy) revealed by geophysical and geochemical approaches: implications for general fluid flow models on volcanoes. J. Volcanol. Geotherm. Res. 196, 111-119. http://dx.doi.org/10.1016/j.jvolgeores.2010.07.022.

Fischer, T.P., Arehart, G.B., Sturchio, N.C., Williams, S.N., 1996. The relationship between fumarole gas composition and eruptive activity at Galeras volcano, Colombia. Geology 24, 531-534.

Fournier, N., Moreau, M., Robertson, R., 2011. Disappearance of a crater lake: implications for potential explosivity at Soufrière volcano, St Vincent, Lesser Antilles. Bull. Volcanol. 73, 543-555. http://dx.doi.org/10.1007/s00445-010-0422-3.

Guichet, X., Zuddas, P., 2003. Effect of secondary minerals on electrokinetic phenomena during water-rock interaction. Geophys. Res. Lett. 30 (13), 1714. http://dx.doi.org/ 10.1029/2003GL017480.

Guichet, X., Jouniaux, L., Catel, N., 2006. Modification of streaming potential by precipitation of calcite in a sand-water system: laboratory measurements in the pH range from 4 to 12. Geophys. J. Int. 166, 445-460. http://dx.doi.org/10.1111/j.1365-246X. 2006.02922.x.

Hantke, G., Parodi, A., 1966. Catalogue of the active volcanoes of the world. Part XIX: Colombia, Ecuador and PeruIAVCEI, Naples (73 pp.).

Hase, H., Ishido, T., Takakura, S., Hashimoto, T., Sato, K., Tanaka, Y., 2003. Z potential measurement of volcanic rocks from Aso caldera. Geophys. Res. Lett. 30 (23), 2210. http:// dx.doi.org/10.1029/2003GL018694.

Hase, H., Hashimoto, T., Sakanaka, S., Kanda, W., Tanaka, Y., 2005. Hydrothermal system beneath Aso volcano as inferred from self-potential mapping and resistivity structure. J. Volcanol. Geotherm. Res. 143, 259-277. http://dx.doi.org/10.1016/j.jvolgeores.2004.12.005.

Inza, L.A., Mars, J.I., Métaxian, J.P., O'Brien, G.S., Macedo, O., 2011. Seismo-volcano source localization with triaxial broad-band seismic array. Geophys. J. Int. http://dx.doi. org/10.1111/j.1365-246X.2011.05148.X.

Inza, L.A., Métaxian, J.P., Mars, J.I., Beanc, C.J., O'Brienc, G.S., Macedo, O., Zandomeneghi, D. 2014. Analysis of dynamics of vulcanian activity of Ubinas volcano, using multicomponent seismic antennas. J. Volcanol. Geoth. Res. 270, 35-52

Ishido, T., 2004. Electrokinetic mechanism for the "W"-shaped self-potential profile on volcanoes. Geophys. Res. Lett. 31, L15616. http://dx.doi.org/10.1029/2004GL020409.

Ishido, T., Mizutani, H., 1981. Experimental and theoretical basis of electrokinetic phenomena in rock-water systems and its applications to geophysics. J. Geophys. Res. $86,1763-1775$.

Ishido, T., Kikuchi, T., Matsushima, N., Yano, Y., Nakao, S., Sugihara, M., Tosha, T., Takakura, S., Ogawa, Y., 1997. Repeated self-potential profiling of Izu-Oshima volcano Japan. J. Geomagn. Geoelectr. 49, 1267-1278.

Jackson, D.B., Kauahikaua, J., 1987. Regional self-potential anomalies at Kilauea volcano. U. S. Geol. Surv. Prof. Pap. 1350, 947-959.

James, D.E., 1982. A combined O, Sr, Nd, and Pb isotopic and trace element study of crustal contamination in Central Andean lavas, I Local geochemical variations. Earth Planet. Sci. Lett. 57, 47-62.

Jouniaux, L., Bernard, M.-L., Zamora, M., Pozzi, J.-P., 2000. Streaming potential in volcanic rocks from Mount Pelée. J. Geophys. Res. 105 (4), 8391-8401.

Kauahikaua, J., 1993. Geophysical characteristics of the hydrothermal systems of Kilauea volcano, Hawaii. Geothermics 22, 271-299.

Keller, G.V., 1988. Rock and mineral properties. In: Nabighian, M.N. (Ed.), Electromagnetic Methods in Applied Geophysics. Soc. Expl. Geophys. , pp. 13-52 (Tulsa)

Lénat, J.-F., 1995. Geoelectric methods in volcano monitoring. In: McGuire, B., Kilburn, C.R. J., Murray, J. (Eds.), Monitoring Active Volcanoes: Strategies, Procedures and Techniques. University College London.

Lénat, J.F., Robineau, B., Durand, S., Bachélery, P., 1998. Etude de la zone sommitale du volcan Karthala (Grande Comore) par polarisation spontanée. C. R. Acad. Sci. 327, 781-788.

Lopez, D.L., Williams, S.N., 1993. Catastrophic volcanic collapse relation to hydrothermal processes. Science 260, 1794-1796.

Lorne, B., Perrier, F., Avouac, J.-P., 1999a. Streaming potential measurements, 1, properties of the electrical double layer from crushed rock samples. J. Geophys. Res. 104, $17,857-17,877$.

Lorne, B., Perrier, F., Avouac, J.-P., 1999b. Streaming potential measurements, 2, relationship between electrical and hydraulic flow patterns from rock samples during deformation. J. Geophys. Res. 104, 17,879-17,896.

Marocco R., del Pino M. 1966. Geología del Cuadrángulo de Ichuña. Comisión carta geológica nacional, Bol 14: pp. 57 and 1 colour map (1/100,000 scale).

Palacky, G.J., 1988. Resistivity characteristics of geologic targets. In: Nabighian, M.N. (Ed.), Electromagnetic Methods in Applied Geophysics. Soc. Expl. Geophys. , pp. 53-130 (Tulsa).

Peltier, A., Finizola, A., Douillet, G., Brothelande, E., Garaebiti, E., 2012. Structure of an active volcano associated with a resurgent block inferred from thermal mapping: the Yasur-Yenkahe volcanic complex (Vanuatu). J. Volcanol. Geotherm. Res. 243-244, 59-68. http://dx.doi.org/10.1016/ j.jvolgeores.2012.06.022.
Reid, M.E., 2004. Massive collapse of volcano edifices triggered by hydrothermal pressurization. Geology 32 (5), 373-376.

Reid, M.E., Sisson, T.W., Brien, D.L., 2001. Volcano collapse promoted by hydrotherma alteration and edifice shape Mount Rainier. Wash. Geol. 29, 779-782.

Revil, A., Leroy, P., 2001. Hydroelectric coupling in a clayey material. Geophys. Res. Lett 28, 1643-1646.

Revil, A., Pezard, P.A., Glover, P.W.J., 1999a. Streaming potential in porous media. 1. Theory of the zeta potential. J. Geophys. Res. 104, 20,021-20,031.

Revil, A., Schwaeger, H., Cathles, L.M., Manhardt, P.D., 1999b. Streaming potential in porous media. 2. Theory and application to geothermal systems. J. Geophys. Res. $104,20,033-20,048$.

Revil, A., Finizola, A., Sortino, F., Ripepe, M., 2004. Geophysical investigations at Strombol volcano, Italy: implications for ground water flow and paroxysmal activity. Geophys J. Int. 157, 426-440. http://dx.doi.org/10.1111/j.1365-246X.2004.02181.x.

Revil, A., Fan, Q., Cary, L., Finizola, A., Trolard, F., 2005. Negative self-potential signals associated with preferential ground water flow pathways in a buried paleo-channel. Geophys. Res. Lett. 32, L07401. http://dx.doi.org/10.1029/2004GL022124.

Revil, A., Finizola, A., Piscitelli, S., Rizzo, E., Ricci, T., Crespy, A., Angeletti, B., Balasco, M. Barde, Cabusson S., Bennati, L., Boleve, A., Byrdina, S., Carzaniga, N., Di Gangi, F. Morin, J., Perrone, A., Rossi, M., Roulleau, E., Suski, B., 2008. Inner structure of La Fossa di Vulcano (Vulcano Island, southern Tyrrhenian Sea, Italy) revealed by highresolution electric resistivity tomography coupled with self-potential, temperature, and $\mathrm{CO}_{2}$ diffuse degassing measurements. J. Geophys. Res. 113, B07207. http://dx. doi.org/10.1029/2007JB005394.

Revil, A., Finizola, A., Ricci, T., Delcher, E., Peltier, A., Barde-Cabusson, S., Avard, G., Bailly, T. Bennati, L., Byrdina, S., Colonge, J., Di Gangi, F., Douillet, G., Lupi, M., Letort, J., Tsang Hin Sun, E., 2011. Hydrogeology of Stromboli volcano, Aeolian Islands (Italy) from the interpretation of resistivity tomograms, self-potential, soil temperature, and soil $\mathrm{CO}_{2}$ concentration measurements. Geophys. J. Int. 186, 1078-1094. http://dx.doi. org/10.1111/j.1365-246X.2011.05112.x.

Rivera, M., 1997. El volcán Ubinas (Sur del Perú): Geología, Historia eruptiva y Evaluación de las amenazas volcánicas actualesUniversidad Nacional de San Marcos, Lima, Perú (Tesis profesional)

Rivera, M., Thouret, J.-C., Gourgaud, A., 1998. Ubinas, el volcán más activo del sur del Perú desde 1550: Geología y evaluación de las amenazas volcánicas. Bol. Soc. Geol. Peru $88,53-71$.

Rivera, M., Thouret, J.-C., Mariño, J., Berolatti, R., Fuentes, J., 2010. Characteristics and management of the 2006-2008 volcanic crisis at the Ubinas volcano (Peru). J. Volcanol. Geotherm. Res. 198, 19-34. http://dx.doi.org/10.1016/j.jvolgeores.2010.07.020.

Rivera, M., Thouret, J.-C., Samaniego, P., Le Pennec, J.-L., 2014. The 2006-2009 activity of Ubinas volcano (Peru): Petrology of the 2006 eruptive products and insights into genesis of andesite magmas, magma recharge and plumbing system. J. Volcanol. Geoth. Res. 270, 122-141.

Sasai, Y., Zlotnicki, J., Nishida, Y., Yvetot, P., Morat, P., Hurukami, H., Tanaka, Y., Ishikawa, Y. Koyama, S., Sekigushi, W., 1997. Electromagnetic monitoring of Miyake-jima volcano, Izu-Bonin Arc, Japan: a preliminary report. J. Geomagn. Geoelectr. 49, 1293-1316.

Sasaki, Y., Yoshihiro, Y., Matsuo, K., 1992. Resistivity imaging of controlled-source audiofrequency magnetotelluric data. Geophysics 57, 952-955.

Sébrier, M., Soler, P., 1991. Tectonics and magmatism in the Peruvian Andes from late Oligocene to the Present. Geol. Soc. Am. Bull. Spec. Pap. 265, 259-278.

Siebert, L., Glicken, H., Ui, T., 1987. Volcanic hazards from Bezymianny- and Bandai-type eruptions. Bull. Volcanol. 49, 435-459.

Simkin, T., Siebert, L., 1994. Volcanoes of the World2nd Edition. Smithsonian Institution, Geosciences Press Inc.(349 pp.).

Stix, J., Zapata, G.J.A., Calvache, V.M.L., Cortès, J.G.P., Fischer, T.P., Gomez, M.D.M., Narvaez, M.L., Ordoñez, V.M., Ortega, E.A., Torres, C.R.A., Williams, S.N., 1993. A model of degassing at Galeras volcano, Colombia, 1988-1993. Geology 21, 963-967.

Strangway, D.W., Swift Jr., C.M., Holmer, R.C., 1973. The application of audio-frequency magnetotelluric (AMT) to mineral exploration. Geophysics 38, 1159-1175.

Thouret, J.-C., Rivera, M., Wörner, G., Gerbe, M.-C., Finizola, A., Fornari, M., Gonzales, K., 2005. Ubinas: the evolution of the historically most active volcano in southern Peru. Bull. Volcanol. 67, 557-589. http://dx.doi.org/10.1007/s00445-004-0396-0.

Tort, A., Finizola, A., 2005. Structural survey of Misti volcanic cone (southern Peru) combining elliptical Fourier function analysis of the volcano morphology and selfpotential measurements. J. Volcanol. Geotherm. Res. 141, 283-297.

Trique, M., Richon, P., Perrier, F., Avouac, J.P., Sabroux, J.C., 1999. Radon emanation and electrical potential variations associated with transient deformation near reservoir lakes. Nature 399, 137-141.

Valdivia, J., 1995. Breve reseña historica del distrito de UbinasBol. del Consejo de Ubinas, Ubinas-Perú (40 pp.).

Vozoff, K., 1991. The magnetotelluric method. In: Nabighian, M.N. (Ed.), Electromagnetic Methods in Applied Geophysics. Soc. of Expl. Geophys, Tulsa, pp. 641-711.

Yasukawa, K., Ishido, T., Suzuki, I., 2005. Geothermal reservoir monitoring by continuous self-potential measurement Mori geothermal field, Japan. Geothermics 34, 551-567.

Zonge, K.L., Hughes, L.J., 1991. Controlled source audiofrequency magnetotellurics In: Nabighian, M.N. (Ed.), Soc. Expl. Geophys. Electromagnetic Methods in Applied Geophysics, 2. 